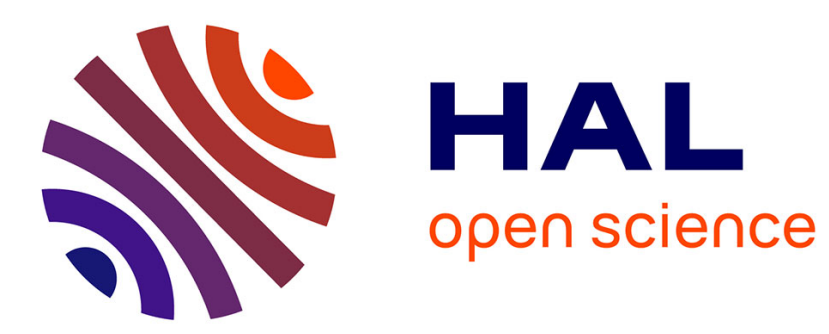

\title{
Ridge offsets, normal faulting, and gravity anomalies of slow spreading ridges
}

\author{
Javier Escartin, Jian Lin
}

\section{To cite this version:}

Javier Escartin, Jian Lin. Ridge offsets, normal faulting, and gravity anomalies of slow spreading ridges. Journal of Geophysical Research: Solid Earth, 1995, 100 (B4), pp.6163-6177. 10.1029/94JB03267 . hal-02323753

\section{HAL Id: hal-02323753 \\ https://hal.science/hal-02323753}

Submitted on 21 Oct 2019

HAL is a multi-disciplinary open access archive for the deposit and dissemination of scientific research documents, whether they are published or not. The documents may come from teaching and research institutions in France or abroad, or from public or private research centers.
L'archive ouverte pluridisciplinaire HAL, est destinée au dépôt et à la diffusion de documents scientifiques de niveau recherche, publiés ou non, émanant des établissements d'enseignement et de recherche français ou étrangers, des laboratoires publics ou privés. 


\title{
Ridge offsets, normal faulting, and gravity anomalies of slow spreading ridges
}

\author{
Javier Escartín ${ }^{1}$ and Jian Lin \\ Department of Geology and Geophysics, Woods Hole Oceanographic Institution, Woods Hole, Massachusetts
}

\begin{abstract}
We develop a model relating mid-ocean ridge normal faulting and crustal structure by examining recently available high-resolution gravity and multibeam bathymetric data of the Mid-Atlantic Ridge and other spreading centers. Results of the analysis reveal a consistent pattern of positive residual gravity anomalies along the crust paralleling all major Atlantic offsets studied, especially along the inside corner side of the offsets. Individual residual gravity anomaly spikes (local peaks), which have amplitudes of up to $20 \mathrm{mGal}$ and typical across-axis spacing of 10-30 km, often coincide with individual major fault scarps, suggesting crust thinned by normal faulting. Theoretical calculations indicate that the amplitude and spacing of the observed residual gravity spikes are consistent with the presence of successive, ridge-parallel low-angle faults that originate episodically at inside corners of ridge offset intersections. Fault scarp heights and the amounts of crustal thinning (as inferred from gravity anomalies) are consistently larger at inside corners than at outside corners, supporting a model in which tectonic extension near ridge offsets is asymmetric with low-angle faults occurring preferentially at inside corners. These results on spatial variations in seafloor morphology and gravity anomalies further support a three-dimensional tectonic faulting model at oceanic spreading centers with three major characteristics: (1) Low-angle faults form preferentially at inside corners, where the mantle lithosphere is the strongest and the lithospheric plates are sufficiently decoupled across ridge axis offsets; (2) low-angle faults decrease in throw toward midpoints of long ridge segments, where large low-angle faults may not be sustained by a weak lithosphere; and (3) the residual gravity peaks are statistically larger at transform than near nontransform offsets, indicating that the length of a ridge offset and its tectonic style control the development of lowangle faults.
\end{abstract}

\section{Introduction}

Recent multibeam bathymetric and gravity mapping along mid-ocean ridges have provided detailed constraints on the architecture of the oceanic crust at ridge segment scale. The existence of distinctive lows in mantle Bouguer gravity anomalies (MBA) at the Mid-Atlantic Ridge (MAR) (Figure 1) indicate that the crust is thicker and the upper mantle is hotter at segment centers than at distal ends [Kuo and Forsyth, 1988; Lin et al., 1990; Blackman and Forsyth, 1991; Morris and Detrick, 1991; Detrick et al., 1995]. These residual gravity lows suggest that magmatic accretion occurs in the form of discrete, buoyancydriven upwelling centers [Kuo and Forsyth, 1988; Lin et al., 1990], thus supporting earlier hypotheses on the existence of melt or buoyant mantle diapirs in the underlying asthenosphere [e.g., Rabinowicz et al., 1984; Whitehead et al., 1984; Crane, 1985; Schouten et al., 1985].

The "bull's eye" gravity lows, however, are of lesser amplitude at segments of fast-spreading ridges such as the East Pacific Rise (EPR) [Madsen et al., 1990; Lin and Phipps Morgan, 1992; Wang and Cochran, 1993; Cormier et al., 1995]. Results from

\footnotetext{
${ }^{1}$ Also at MIT/WHOI Joint Program in Oceanography, Woods Hole Oceanographic Institution, Woods Hole, Massachusetts.
}

Copyright 1995 by the American Geophysical Union.

Paper number 94JB03267.

0148-0227/95/94JB-03267\$05.00 numerical experiments on upper mantle convection [Parmentier and Phipps Morgan, 1990; Sparks et al., 1993] suggest a transition from three-dimensional plumelike mantle upwelling to two-dimensional sheetlike upwelling with increasing spreading rate which is consistent with the observed spreading rate dependence of ridge axis gravity structure [Lin and Phipps Morgan, 1992]. The range of MBA amplitudes decreases with increasing spreading rate (Figure 2).

Estimates of gravity-derived crustal thickness along the MAR are in general agreement with results from limited seismic experiments, which also indicate thicker crust at segment centers than at segment ends [Sinha and Louden, 1983; Tolstoy et al., 1993]. The observed reduction in seismic crustal thickness toward ridge offsets corresponds mainly to the thinning of layer 3 (cumulate gabbros), whereas the thickness of layer 2 (basalt and diabase) remains essentially constant, as interpreted by Tolstoy et al. [1993]. This seismic interpretation of crustal structure is consistent with the model of focused mantle upwelling, as the increased availability of melt at the segment center would result in a greater rate of crustal emplacement and a thicker section of gabbros (layer 3) than at distal ends, where the melt supply would be reduced. Alternatively, the variations in the seismic structure could be interpreted in terms of compositional variations of the crust [Cannat, 1993]. The limited seismic refraction and tomography study by Tolstoy et al. [1993] suggests that gravityderived models may underestimate, rather than overestimate, the amplitude of seismic crustal thickness variations, and theoretical calculations indicate that mantle density may contribute only a 


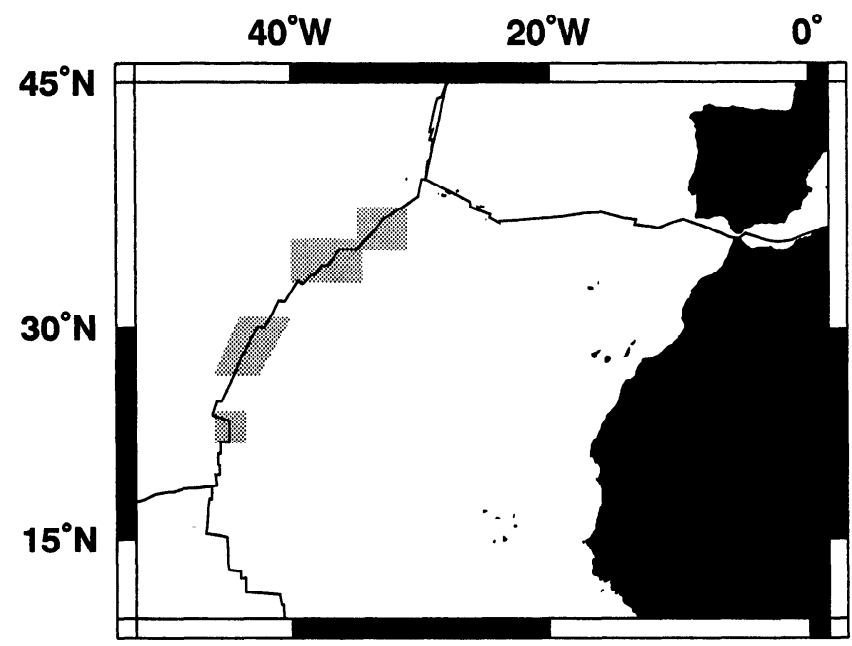

Figure 1. Location map of study areas (light shading) at the Mid-Atlantic Ridge where multibeam bathymetric and residual gravity data are available. Sources for individual data sets are listed in Table 1. Location of plate boundary is indicated by thin lines.

small amount to the observed residual gravity anomalies [Lin and Phipps Morgan, 1992; Sparks et al., 1993].

The interpreted focused mantle upwelling and the resultant along-axis variations in crustal thickness may also have important effects on the thermo-mechanical properties of the oceanic lithosphere at the ridge axis [Neumann and Forsyth, 1993; Shaw and Lin, 1993]. Theoretical models of Shaw and Lin [1994] suggest that the decoupling of the upper crust from the mantle by a weak lower crust may occur only at segment centers ("pita pocket" structure), resulting in a thin, weak lithosphere at segment centers and a thick, strong lithosphere at distal ends. The thin lithosphere over the weak lower crust will favor the formation of small and closely spaced faults at the segment centers [e.g., Shaw and Lin, 1993]. This model is consistent with several lines of observations: (1) the clustering of teleseismic earthquakes in the proximity of ridge offsets [Huang and Solomon, 1988; Lin and Bergman, 1990], where the mantle lithosphere is the strongest; (2) the systematic deepening of axial seafloor depth toward segment ends [Sempéré et al., 1993]; and (3) the occurrence of smaller, more closely spaced scarps inferred to be faults at segment centers than at distal ends [Shaw, 1992; Shaw and Lin, 1993] (Plates 1a and 1b). These fault scarps tend to be axis parallel at segment centers and to become oblique near offsets [Escartín and Lin, 1992], probably as a result of the interaction of far- and near-field stresses in the vicinity of ridge offsets [e.g., Fujita and Sleep, 1978; Pollard and Aydin, 1984].

The tectonic interaction of the ridge axis and offsets at slowand intermediate-spreading centers is most evident in the remarkable contrast between elevated crust at ridge offset inside corners (ICs) and depressed seafloor at conjugate outside corners (OCs) (Plate 1) [e.g., Searle and Laughton, 1977; Karson and
Dick, 1983; Kuo et al., 1984; Collette, 1986; Severinghaus and Macdonald, 1988; Blackman and Forsyth, 1989; Mutter and Karson, 1992]. Significant differences in lithology between IC and $\mathrm{OC}$ crust have also been found in dredged rock samples. Upper mantle and lower crustal rocks are frequently dredged at IC crust, suggesting that low-angle faults may locally expose the lower crust and upper mantle there [Karson and Dick, 1983, 1984; Dick, 1989; Dick et al., 1991; Mével et al., 1991; Tucholke and Lin, 1994]. In contrast, mantle and lower crustal rocks were rarely found at $\mathrm{OC}$ crust or at segment centers [Tucholke and Lin, 1994]. Higher values of residual gravity anomalies similarly indicate greater amount of crustal thinning at IC crust than at OC crust (Plates 1c and 1d). Recent studies of micro-earthquakes at the MAR further documented strong clustering of seismic events at ICs and little activity at OCs, indicating that IC crust is seismically more active [Barclay et al., 1993; Wolfe et al., Microearthquake characteristics and crustal velocity structure at $29^{\circ} \mathrm{N}$ on the Mid Atlantic Ridge: The architecture of a slowspreading segment, submitted to Journal of Geophysical Research, 1995]. In addition, significant differences in tectonic style exist between transform and nontransform offsets. Transform offsets are characterized by a well-defined strike-slip fault running within a transform valley, while nontransform often lack a well-defined transform fault and tend to have smaller lateral ridge offsets [Macdonald et al., 1991].

In this paper we analyze high-resolution gravity and bathymetry data collected over several ridge offset intersections along the MAR (Figure 1) and other spreading centers to better understand the processes responsible for tectonic differences between IC and OC crust. We then analyze these anomalies in terms of the structure of individual faults and study the

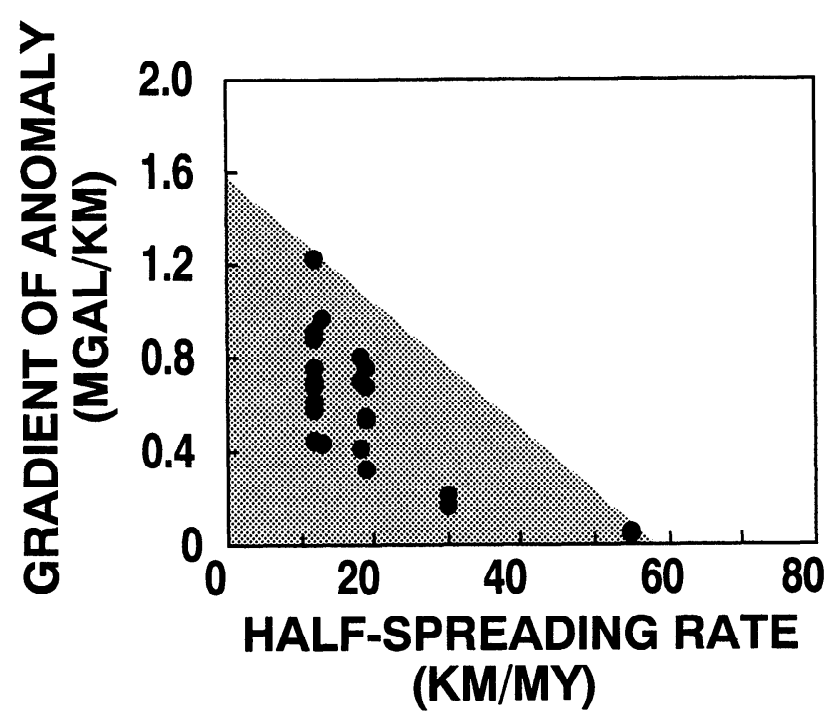

Figure 2. Along-axis gradients in mantle Bouguer gravity plotted against spreading rate (modified from Lin and Phipps Morgan [1992]). Note that both the gradient and its variation decrease with spreading rate (fan-shaped shaded area).

Plate 1. Oblique projection of shaded relief maps of (a) the Atlantis Fracture Zone (F. Z.) and (b) a ridge segment bounded by two nontransform offsets at the Mid-Atlantic Ridge $\left(\sim 29^{\circ} \mathrm{N}\right)$. Note that inside corners near both transforms and nontransform offsets are elevated and show large abyssal hill relief, which we interpret as due to large throw faults. In contrast, outside corners are depressed and show closely spaced fault scarps with smaller throws. Color residual gravity anomaly plotted on top of 3-D bathymetric meshes for (c) a segment north of the Atlantis F. Z. and (d) a segment bounded by two nontransform offsets. Note that inside corners are often associated with high residual gravity anomalies, indicating thinned crust. IC; inside corner; OC; outside corner. 

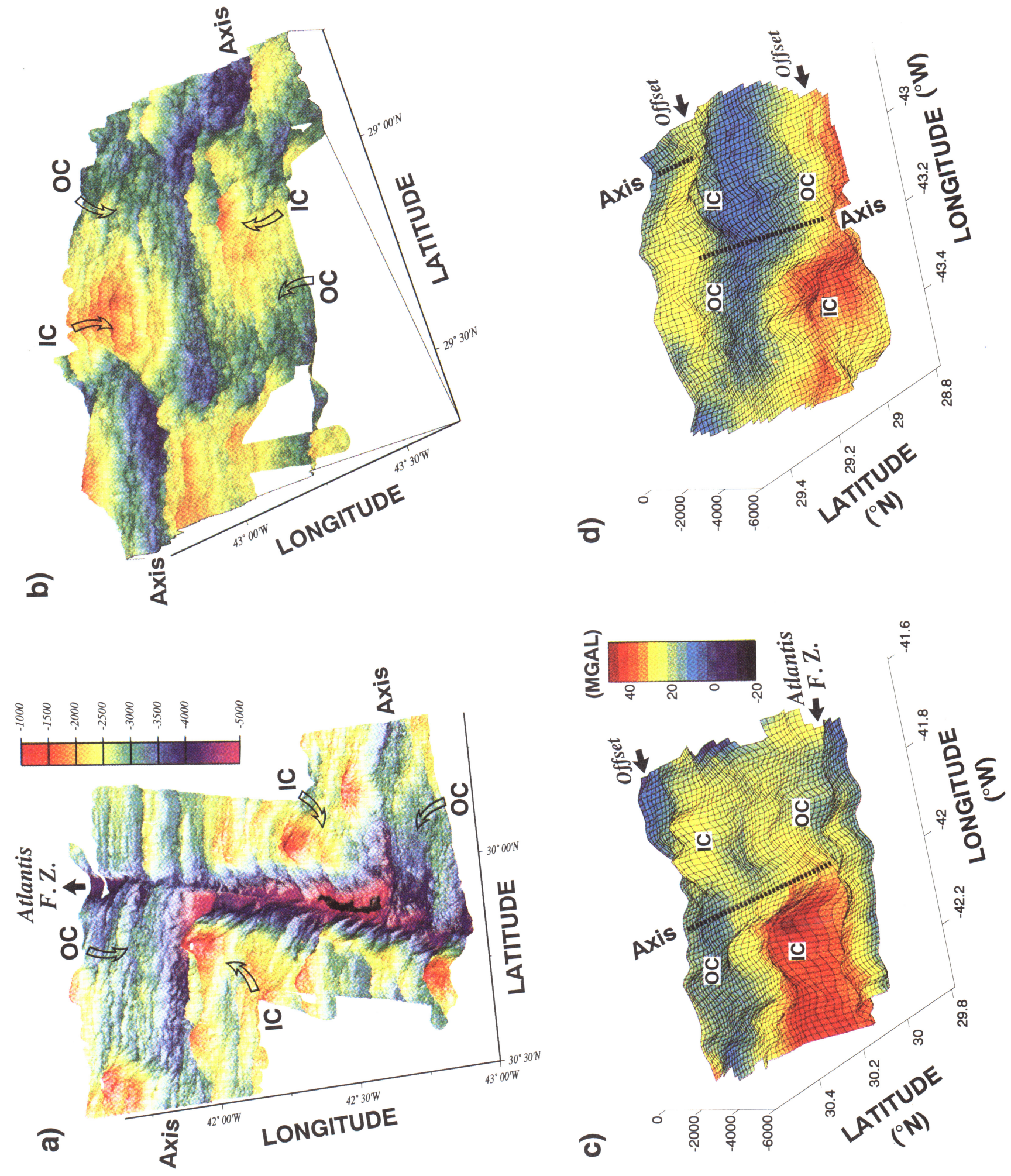
relationship between these anomalies, offset styles, and crustal accretion variables of spreading rate, ridge offset length, and axial valley relief. Finally, we compare the data with synthetic results of two-dimensional kinematic models of crustal faulting. Through these analyses, we attempt to develop a threedimensional tectonic model for the formation of IC and OC crust in rclation to transform and nontransform ridge offsets.

\section{Data Analysis}

We examine digital multibeam bathymetric and residual gravity data collected over four areas of the slow-spreading MAR [Purdy et al., 1990; Lin et al, 1990; Morris and Detrick, 1991; Detrick et al., 1995] (Figure 1), two areas of the fast-spreading EPR between $7^{\circ}-9^{\circ} 30^{\prime}$ S [Wang and Cochran, 1993] and $8^{\circ} 50^{\prime}-$ $9^{\circ} 50^{\circ} \mathrm{N}$ [Madsen et al., 1990], and the very slow-spreading Southwest Indian Ridge (SWIR) near the Atlantis II Transform [Dick et al., 1991; Dick, unpublished data, 1990]. These data sets encompass a total of 8 transforms and 14 nontransform offsets with age offsets from 0.1 to $23 \mathrm{Ma}$ and half-spreading rates from 0.8 to $7.7 \mathrm{~cm} / \mathrm{yr}$. Additional data from the southern MAR [Kuo and Forsyth, 1988; Blackman and Forsyth, 1991; Neumann and Forsyth, 1993] show similar IC/OC asymmetry but were not included in this study due to less dense coverage of the IC and $\mathrm{OC}$ areas. In each data set studied, residual mantle Bouguer anomalies (RMBA) are derived by subtracting from the free-air anomaly the following predictive components: (1) the effects of water-crust and crust-mantle interfaces assuming a reference 6$\mathrm{km}$-thick crust and water, crust and mantle densities of 1030 , 2700 and $3300 \mathrm{~kg} / \mathrm{m}^{3}$, respectively; and (2) the effects of mantle density changes due to lithospheric cooling [Kuo and Forsyth, 1988; Lin et al., 1990] based on a three-dimensional model of passive mantle upwelling [Phipps Morgan and Forsyth, 1988]. We infer crustal thickness variations primarily from the RMBA data since little seismic refraction data are currently available at either IC or OC crust along slow spreading centers [cf. Detrick et al., 1993].

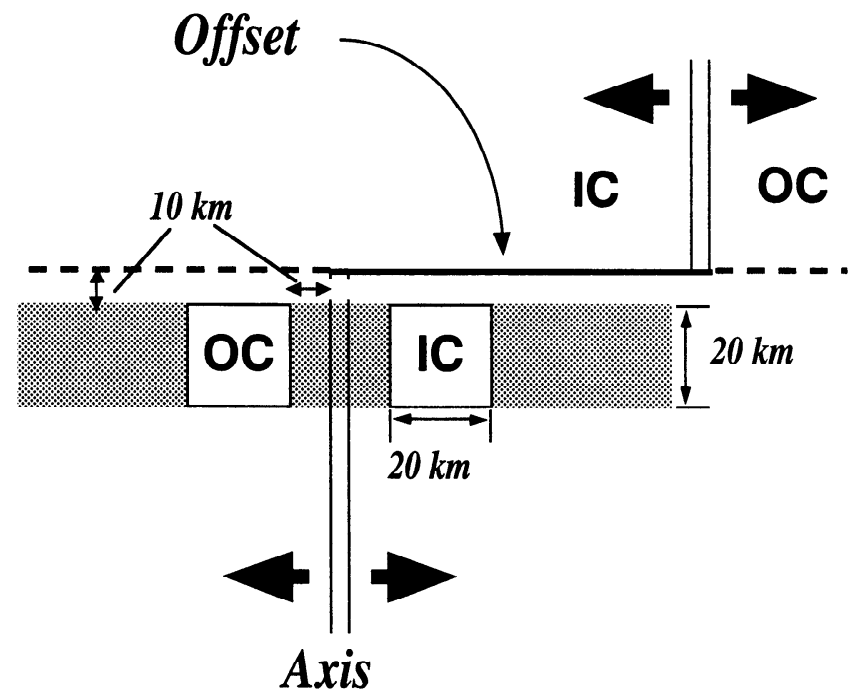

Figure 3. Method of defining the differences between IC and OC crust. Average across-axis profiles in bathymetry and gravity are calculated by stacking and averaging several profiles along each corridor (shaded area). To define an average IC/OC asymmetry we subtract the average depth in the conjugate IC and OC boxes $(20 \mathrm{~km} \times 20 \mathrm{~km}$ each), following the method of Severinghaus and Macdonald [1988].

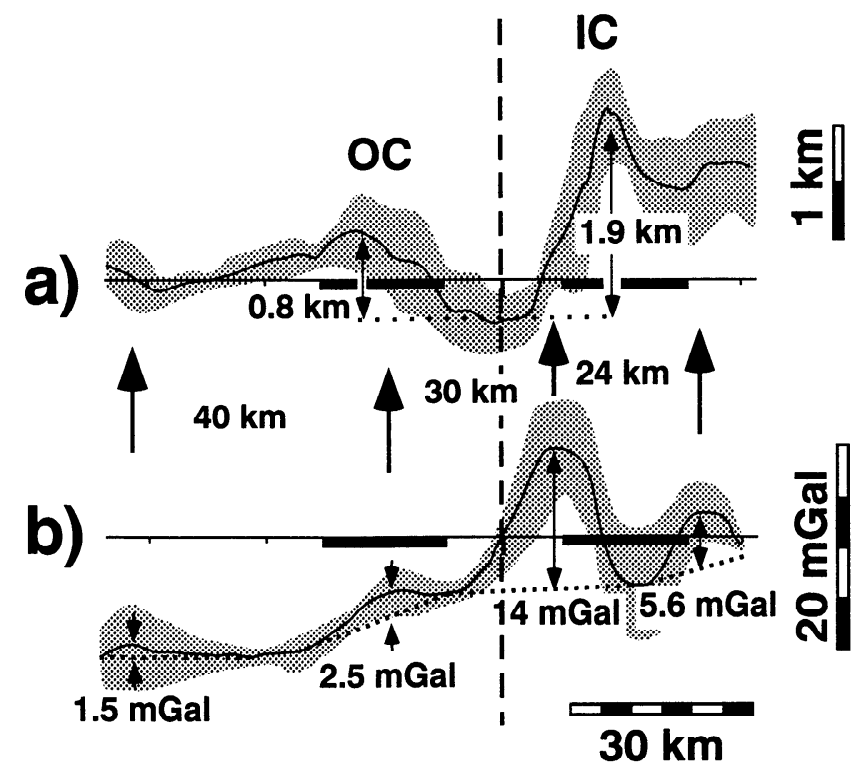

Figure 4. Examples illustrating methodology in measuring (a)individual fault scarps and (b) gravity spikes. (Data from the Oceanographer F. Z. in Figure 5.) The average profiles are marked by solid lines, and $1 \sigma$ deviations are denoted by shaded regions. Thick bars on horizontal axis marks the location of the small IC and OC boxes shown in Figure 3. Location of local gravity peaks, which are interpreted as fault related, is marked by single-headed arrows; the spacing between successive relative gravity peaks is given in kilometers. Vertical relief on a fault scarp is measured from the axial valley floor. Amplitudes of individual gravity peaks (double-headed arrows) are calculated from a chosen baseline (dotted line) that connects points between low values. Since the choice of the baseline is somewhat subjective, maximum and minimum amplitudes are estimated for each gravity peak using different baselines.

In each study area we define a 20 -km-wide corridor that lies parallel to the trace of a ridge offset crossing the spreading axis (shaded area in Figure 3). This corridor is located $\sim 10 \mathrm{~km}$ away from the offset to avoid inclusion of transform fault valleys or nontransform basins. For those segments with along-axis length of less than $40 \mathrm{~km}$, the corridor width is reduced to less than 20 $\mathrm{km}$ in order to prevent overlapping between corridors at two ends of a common segment. Bathymetric and RMBA profiles were calculated for each corridor (Figure 4). From these profiles we then identified and measured the location of individual gravity spikes (local peaks), the spacing between the peaks, the relative amplitudes of the peaks, and the vertical relief of the associated fault scarps (Figure 4).

The bathymetry and residual gravity profiles from both transforms (Figure 5) and nontransform offsets (Figure 6) reveal several systematic pattcrns. The residual gravity profiles are characterized by a succession of relative gravity peaks spaced 10 to $50 \mathrm{~km}$ (Figures 5 and 6), with average spacing of $16 \mathrm{~km}$ between off-axis peaks and $27 \mathrm{~km}$ for the nearest peaks abutting the ridge axis (Figure 7). The first pair of gravity peaks on either side of the ridge axis are consistently associated with fault scarps bounding the inner valley floor (e.g., profile 6, Figure 5; profile 18 , Figure 6), although some profiles are too short to characterize the full shape of a peak (e.g., profile 16, Figure 6). The amplitude of the gravity peaks can reach $20 \mathrm{mGal}$ and tends to increase with increasing relief on the corresponding fault scarps 


\section{Oceanographer $(\mathrm{N})$}

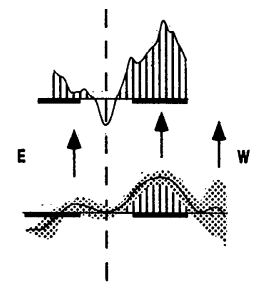

2. Oceanographer (S)

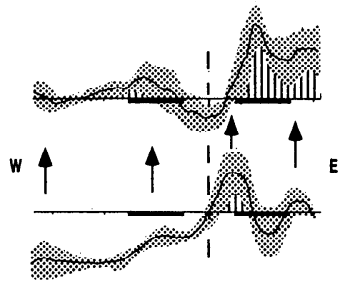

3. Hayes (S)
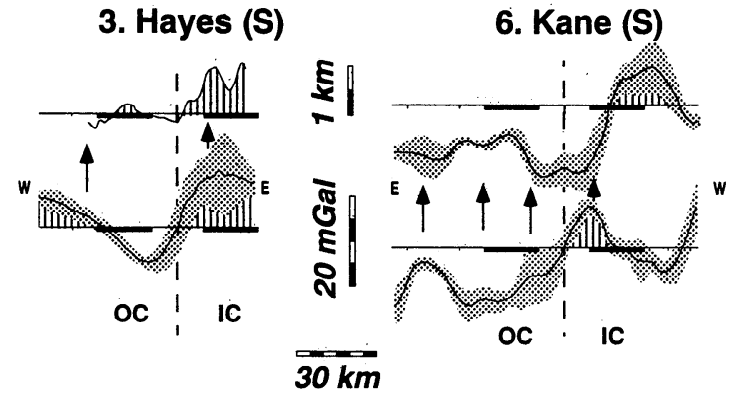

Figure 5. Averaged across-axis profiles in bathymetry and residual gravity for the transform offsets listed in Table 1. For each transform the upper profile corresponds to bathymetry and the lower profile to gravity. E and W mark east and west, respectively. Arrows indicate the location of local gravity peaks.

(Figure 8). Furthermore, larger fault scarps and gravity peaks are consistently associated with IC crust.

To define a value of across-axis asymmetry; values of bathymetry and gravity were averaged over a conjugate pair of 20 $\mathrm{km} \times 20 \mathrm{~km}$ boxes at IC and OC crust, following the method of Severinghaus and Macdonald [1988]. The difference in the averaged values between the IC and OC boxes is then defined as the average asymmetry. For each site we also define a maximum asymmetry, which represents the largest difference between axisparallel profiles that are located $15-25 \mathrm{~km}$ on oppositc sides of the ridge axis and run over the highest IC topography [Severinghaus and Macdonald, 1988]. In our discussion, however, we refer primarily to the average asymmetry since it is a lesser subjective meásurement. We also measured rift valley relief and ridge offset length using Severinghaus and Macdonald's [1988] method (Table 1).

Results in Table 1 show that the average IC/OC asymmetries are significantly larger near transforms than nontransform offsets: the bathymetric asymmetry of individual transforms ranges from 0.4 to $1.0 \mathrm{~km}$ with a mean of $0.8 \mathrm{~km}$. In contrast, the asymmetry of nontransform offscts ranges from 0.0 to $0.8 \mathrm{~km}$ with a mean of $0.4 \mathrm{~km}$. Similarly, the gravity asymmetry of transforms ranges from 4.4 to $17.6 \mathrm{mGal}$ with a mean of $10 \mathrm{mGal}$, whereas asymmetry of nontransform offsets ranges from -0.3 to 14.2 $\mathrm{mGal}$ with a mean of $5.7 \mathrm{mGal}$. These data suggest that although the crust is more elevated and thinner at all ICs, the anomalies are greater at transforms than at nontransform offsets.

The average asymmetry data also reflect fundamental differences in gross morphology between fast and slow spreading ridges (Table 1 and Figure 9). The fast spreading EPR (5.5-7.7 $\mathrm{cm} / \mathrm{yr}$ half rate) is characterized by an axial high and more symmetrical IC and OC crust (Figures 9a and 9d). This is in contrast to the large variabilities in average asymmetry values for the slow spreading MAR and SWIR $(0.8-1.4 \mathrm{~cm} / \mathrm{yr}$ half rate). Within the slow spreading ridges, however, there is little correlation between average asymmetry and axial valley relief (correlation factor $r^{2}<0.1$ in all cases) (Figures 9c and 9f). Severinghaus and Macdonald [1988] suggested a linear relationship between these two parameters (dotted line in Figure 9c) that was not resolved by our limited data set. Consistent with the results from individual fault scarps (Figure 8), the average asymmetry is in general greater near transform than nontransform offsets (Figures $9 \mathrm{~b}$ and 9e).

\section{Crustal Thinning Models}

To investigate possible contributions of normal faults to the observed gravity anomaly spikes, we examine in detail twodimensional, axis-perpendicular kinematic models of crustal faulting. Using these models we calculate gravity anomalies associated with single and multiple faults, study the sensitivity of gravity anomalies to changes in fault geometry and crustal thickness, and compare theoretical results with the observed MAR data. We intcrpret the data using an end-member model of normal faulting. Other factors such as crustal density and thickness variations may also affect the gravity structure but are not the focus of this study.

\section{Kinematic Models}

Our model assumes a faulted elastic lithospheric layer overlying an inviscid, ductile mantle [King et al., 1988; Stein et al., 1988; Weissel and Karner, 1989; Lin and Parmentier, 1990]. The flexural response of the lithosphere is calculated for given combinations of fault geometry, effective elastic thickness $\left(T_{e}\right)$, and density structure (Figure 10).

We examined both planar and listric fault geometries (Figure 11). In the case of a planar fault, dip angle $(\alpha)$ and downdip slip (s) are two critical parameters (Figures 11c and 11d). In the case of a listric fault, we define a detachment depth (where the fault becomes horizontal) and a dip angle at the seafloor; the fault curvature corresponds to an arc circle (Figures 11a and 11b). Displacement along the fault is imposed using a constant heave model [e.g., Gibbs, 1983] that assumes constant horizontal displacement [Dula, 1991]. Submersible observations show that fault scarps on the seafloor have slopes from less than $30^{\circ}$ to $60^{\circ}$ [Macdonald and Luyendyk, 1977; Karson and Dick, 1983, 1984; Mével et al., 1991]; however, slopes derived from multibeam data rarely exceed $40^{\circ}$ [Escartín and Lin, 1992]. In addition to deteriorating effects from mass wasting [Tucholke, 1992], talus accumulation, and sedimentation, the low apparent slopes in multibeam data may be largely due to inability of multibeam systems (footprint size of $\sim 150 \mathrm{~m} \mathrm{x} 150 \mathrm{~m}$ ) to accurately resolve individual fault scarps. Thus good constraints on the dip angle of fault scarps cannot be accurately measured from available multibeam bathymetric data. Studies in ophiolites [e.g., Alexander and Harper, 1992; Alexander et al., 1993] suggest that faults can be low-angle and propagate into the mantle and that the 


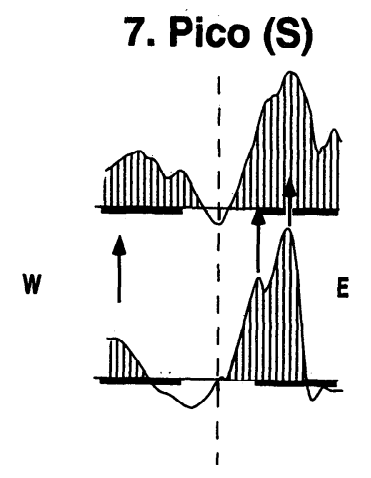

8. FAMOUS B (N)

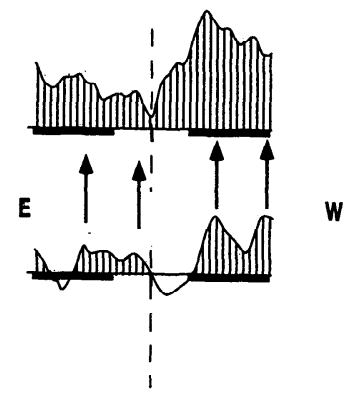

9. F.Z. I (N)

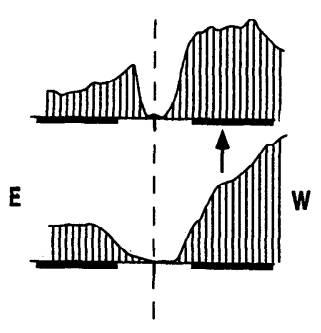

10. F. Z. I (S)
11. $34^{\circ} 05^{\prime} \mathrm{N}(\mathrm{N})$

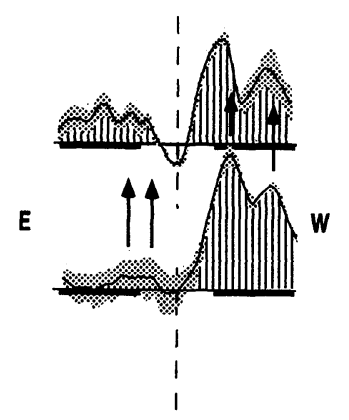

12. $30^{\circ} 30^{\prime} \mathrm{N}(\mathrm{S})$

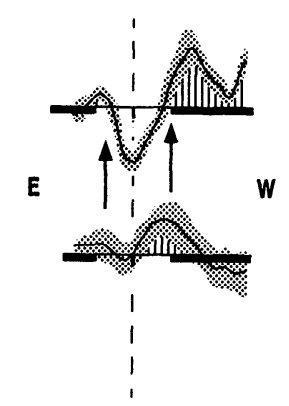

13. NOMARK 1 (N)

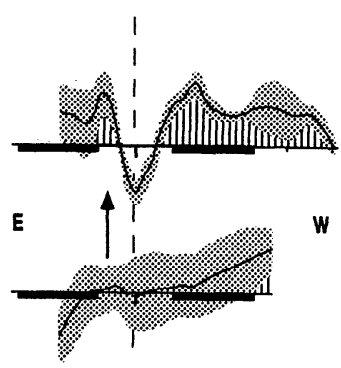

14. NOMARK 1 (S)
15. NOMARK 2 (N)

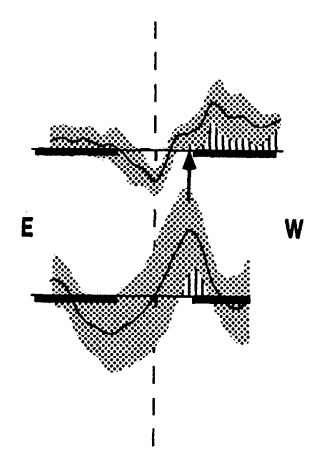

16. NOMARK 3 (S)

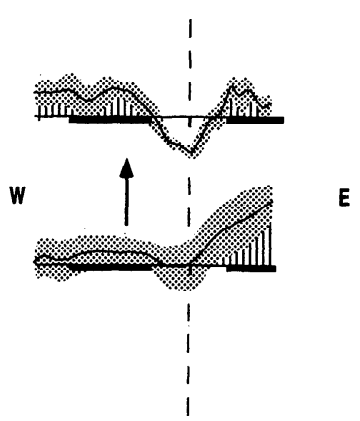

17. MARK 1 (N)

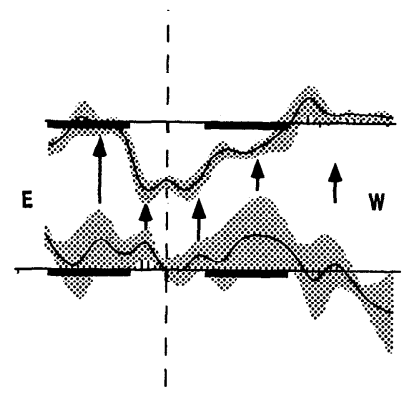

18. MARK 1 (S)
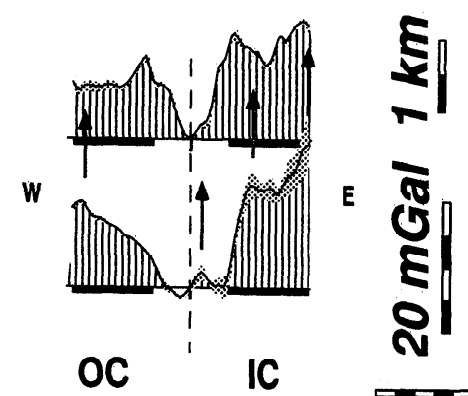

$E$

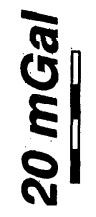

$3 \overline{\mathrm{km}}$
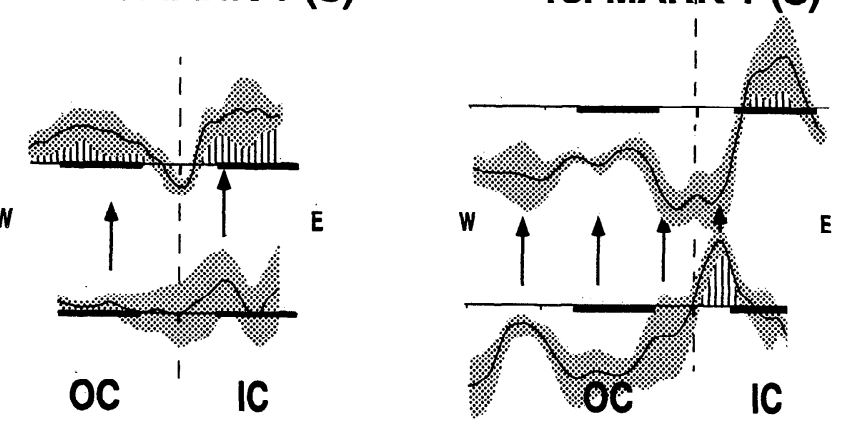

Figure 6. Averaged across-axis profiles in bathymetry and residual gravity for nontransform offsets listed in Table 1. See Figure 5 for explanations.

existence of a ductile layer in the lower crust or upper mantle could favor the formation of listric faults [Harper, 1985]. Such low-angle faults would exhumate mantle rocks at ICs of ridge offsets [e.g., Karson, 1990; Mével et al., 1991; Tucholke and Lin, 1994] and their dip could be rotated to lower angles [Buck, 1993].
Estimates of the effective elastic thickness in the vicinity of slow-spreading ridge axes range from 2 to $13 \mathrm{~km}$ [McKenzie and Bowin, 1976; Cochran, 1979; Louden and Forsyth, 1982; Blackman and Forsyth, 1991; Neumann and Forsyth, 1993]. As the gravity anomaly is insensitive to the assumed $T_{e}$ (Figure 10c), 


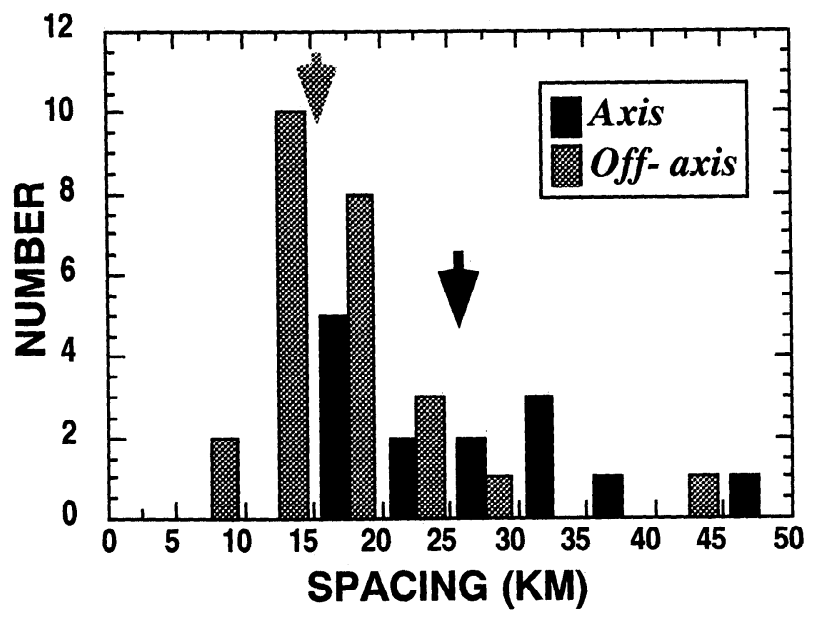

Figure 7. Histogram of measured spacings between successive gravity peaks from the profiles shown in Figures 5 and 6 . We have separated the spacing values measured between peaks abutting the ridge axis (axis, black bars), and those measured between peaks off axis (off-axis, shaded bars). Arrows indicate the averages for each population $(16 \mathrm{~km}$ for the off-axis data and $27 \mathrm{~km}$ for the axis data).

for the rest of our calculations we adopt $T_{e}=3 \mathrm{~km}$, which is the average value reported for the MAR between the Kane and Atlantis transforms [Ruppel and Shaw, 1992] and appropriately fits the observed topography.

We assume densities of 1030 and $3300 \mathrm{~kg} / \mathrm{m}^{3}$ for the water and upper mantle, respectively, and an average crustal density of $2750 \mathrm{~kg} / \mathrm{m}^{3}$. The results of residual gravity anomaly for a threelayer or a five-layer crust with density increasing from 2600 at surface to $2900 \mathrm{~kg} / \mathrm{m}^{3}$ right above the Moho are practically identical to each other; they differ only slightly from the singlelayer crust model with an uniform density of $2750 \mathrm{~kg} / \mathrm{m}^{3}$ (Figure 10b). We thus use the three-layer crust model in our discussion. The gravitational effects of various density interfaces were calculated using the upward continuation method of Parker [1973].

\section{Sensitivity to Fault Parameters}

Given the lack of good, direct constraints on fault configurations at depth, we examined a range of planar and listric fault geometries with different dip angles and detachment depths. These models allow us to predict the sensitivity of gravity anomalies to changes in model fault parameters, and the theoretical results can be used to compare with the observed RMBA.

Examples of two listric and two planar faults with vertical relief of $2 \mathrm{~km}$ each are shown in Figure 11. In the cases of listric faults, the dip angle at the seafloor is $45^{\circ}$ and detachment depths are $7 \mathrm{~km}$ (Figure 11a) and $3 \mathrm{~km}$ (Figure 11b), respectively. For planar faults we examined cases with dip angle of $45^{\circ}$ (Figure 11c) and $30^{\circ}$ (Figure 11d), respectively. Although all four configurations have a very similar surficial expression, the predicted gravity anomalies vary from $\sim 6$ to $\sim 18 \mathrm{mGal}$. The predicted anomaly is largest $(\sim 18 \mathrm{mGal})$ for the low-angle planar fault that propagates into the mantle (case d), and smallest ( $\sim 6$ $\mathrm{mGal}$ ) for the listric fault confined to the crust (case b). When propagating into the mantle, both the listric (case a) and highangle planar fault (case $\mathrm{c}$ ) yield anomalies of $\sim 10 \mathrm{mGal}$. These results suggest that large gravity anomalies may be found only where faults propagate deep enough to disturb the crust-mantle interface, whereas if faults are restricted to within the crust the anomalies will be small. Since the noise level of sea surface gravity data is between 2 and $5 \mathrm{mGal}$, only those faults with relatively large vertical throws are detectable. The model also indicates that the gravity anomaly is located at the base of the fault scarp (Figures 11 and 12) at a distance that will depend on the fault angle and slip as well as the crustal thickness. Such a relationship between the gravity peak and the fault scarp can be observed in many of the profiles in Figures 5 and 6 . For cases in which such correlation does not hold (e.g., profiles 10 and 11, Figure 6), the gravity anomaly might be caused by off-axis variations in density or crustal thickness not associated with faulting.

Tectonic extension of the oceanic crust through normal faulting is thought to be between $10 \%$ and $20 \%$ of the total seafloor spreading for slow spreading ridges [Macdonald and Luyendyk, 1977; Solomon et al., 1988]. In the simplest case of multiple faults with identical dip angles and displacements, we
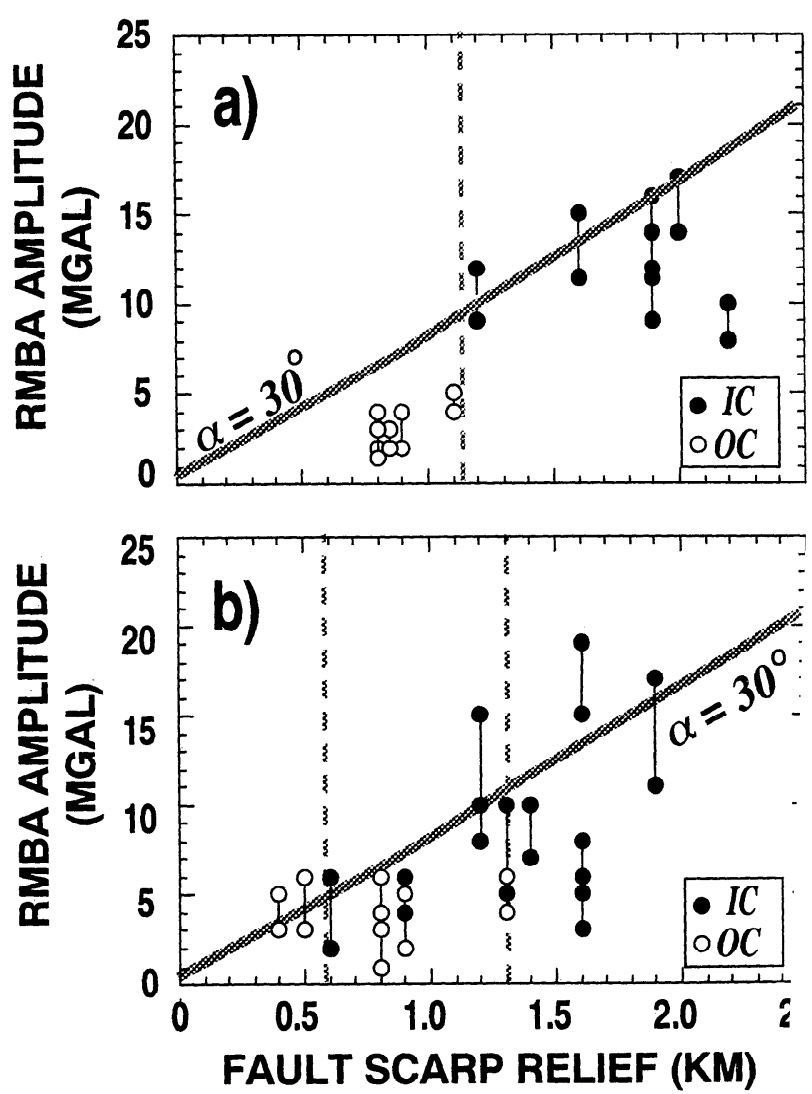

Figure 8. Measured amplitude of RMBA peaks plotted a function of fault scarp relief for profiles parallel to (a) transfor and (b) nontransform offsets. Only the first gravity peaks each side of the ridge axis are considered, and the estima maximum and minimum values are shown (connected do Note that fault scarps associated with IC crust (solid circles) $h$ larger relief and associated RMBA than those of OC crust (o circles). The transition between IC and OC crust in term: relief on fault scarps occurs at $\sim 1.5 \mathrm{~km}$ for transforms (Figure and $0.6-1.3 \mathrm{~km}$ for nontransform offsets (dashed lines). Incl: gray lines mark a theoretical relationship between gra anomaly and fault throw for a $30^{\circ}$ dipping fault that is separ $50 \mathrm{~km}$ from the nearest faults (See Figure 13 for fur explanation). 


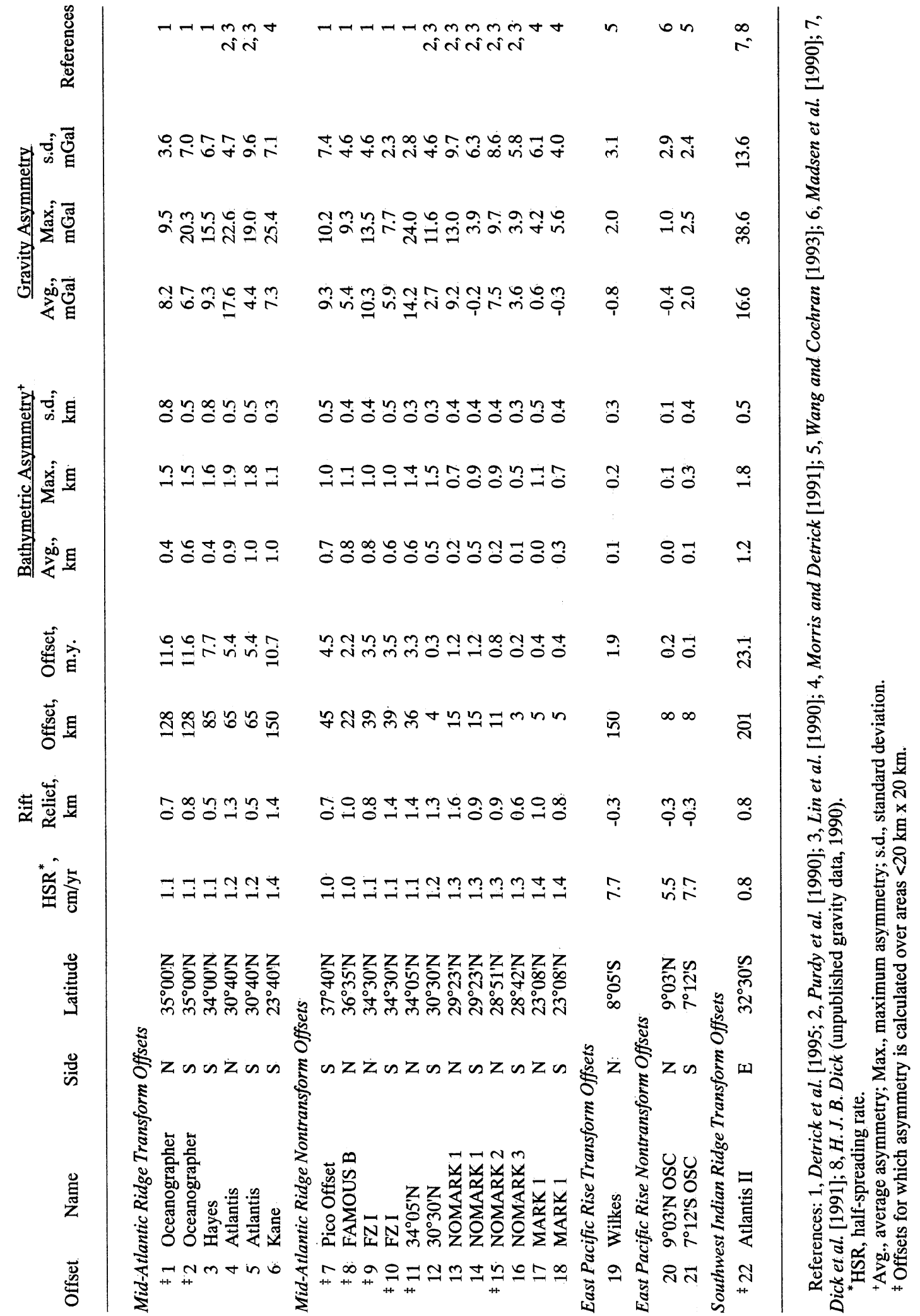



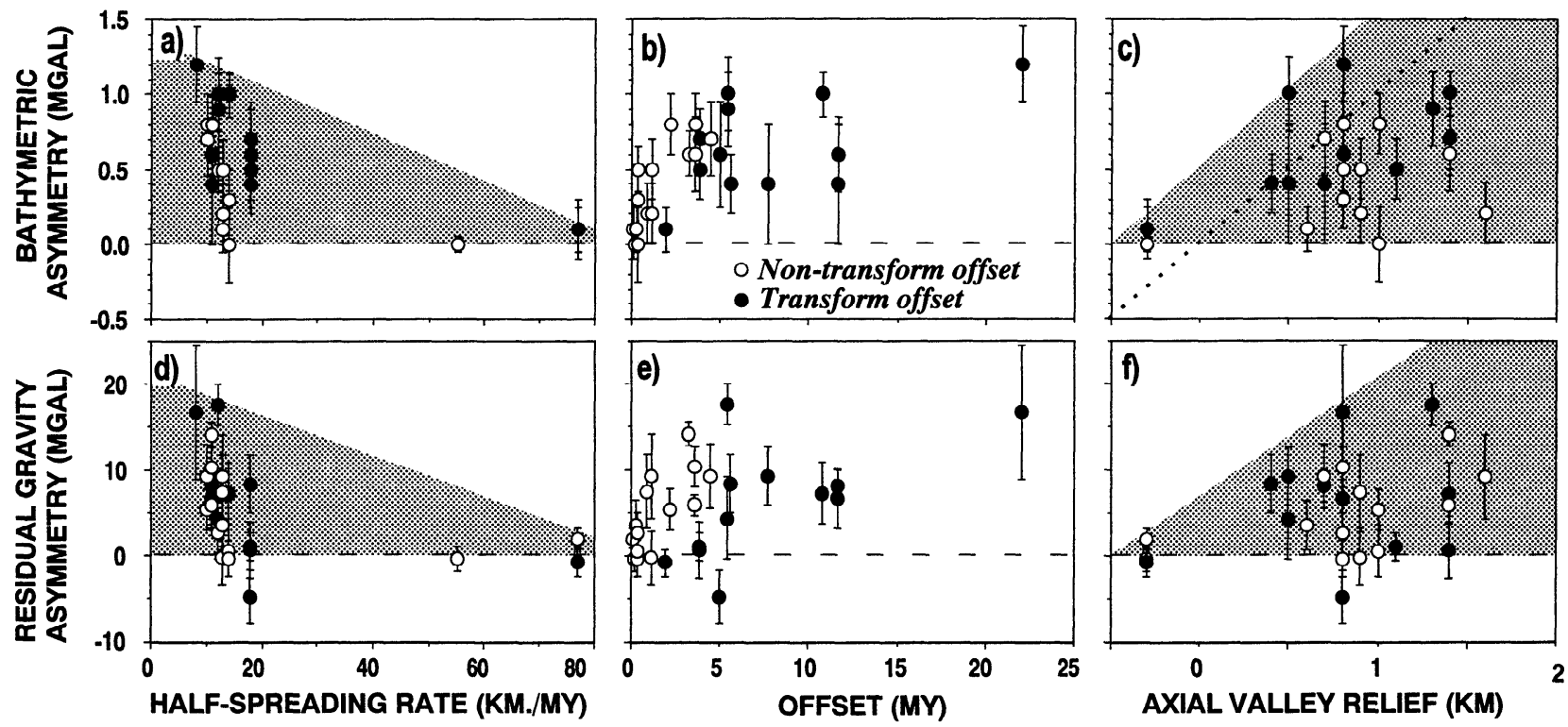

Figure 9. (a)-(c) Average asymmetry in bathymetry and (d)-(f) residual gravity as a function of half-spreading rate (Figures 9a and 9d), age offset (Figures 9b and 9e), and axial valley relief (Figures 9c and 9f). Error bars mark $1 \sigma$ standard deviation. Dashed lines mark zero asymmetry. The dotted line in Figure 9c shows a linear relationship proposed by Severinghaus and Macdonald [1988]. The fan-shaped shaded areas illustrate that variations in asymmetry decrease with decreasing axial valley relief and increasing spreading rate. Open circles: nontransform offsets; closed circles: transform offsets.

can express the proportion of tectonic extension (faulting) to magmatic accretion as the ratio between the horizontal displacement on individual faults (heave) and the spacing between the successive faults. In Figure 12 we present two different multiple-fault models, both with dip angle of $45^{\circ}$ and $10 \%$ of seafloor spreading by tectonic extension. In case a, faults

a)

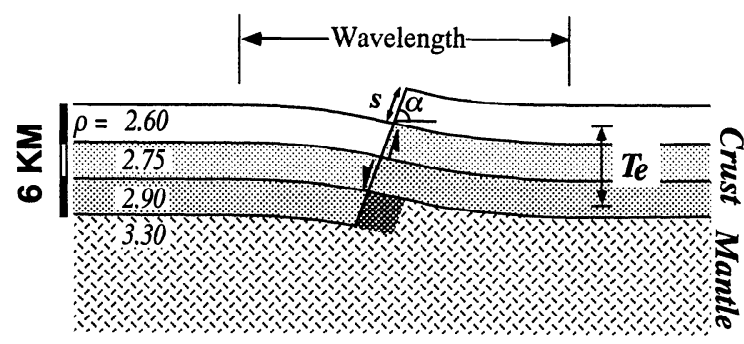

b)

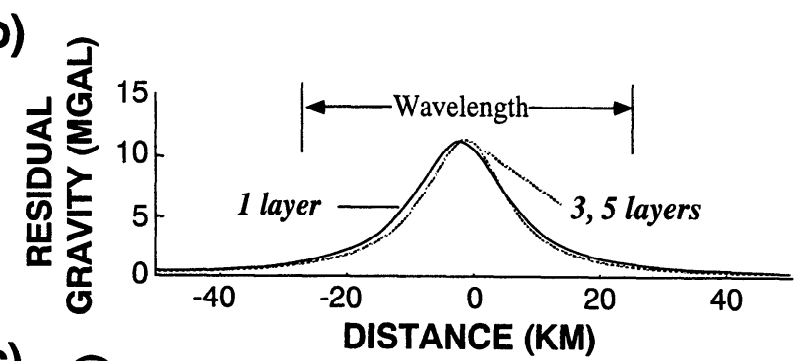

c)

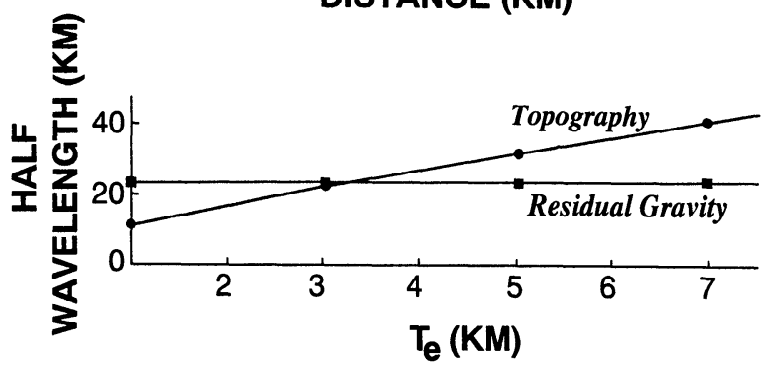

are spaced $10 \mathrm{~km}$ apart with horizontal displacements of $1 \mathrm{~km}$ each, whereas in case b, faults are spaced $30 \mathrm{~km}$ apart with displacement of $3 \mathrm{~km}$ each. These values are comparable to the observed spacings and vertical reliefs on the northern MAR faults (Figure 5). These two cases show clear differences in the gravity anomaly: the peak-to-trough anomaly is practically negligible $(\sim 3 \mathrm{mGal})$ for closely spaced faults with moderate throws (case a), whereas the anomaly is large $(\sim 13 \mathrm{mGal})$ for widely spaced faults with large throws (case b). The peaks in the gravity anomaly (arrows) are located in front of the associated fault scarps, similar to the observed correlation between gravity spikes and fault scarps at the MAR (e.g., profiles 2 and 5 in Figure 5). Small fault scarps not identifiable in Sea Beam can exist [e.g., Mitchell, 1991; Cowie et al., 1993] and have not been considered as the anomalies associated with them are too small to be detected on the shipboard gravity data.

Our models reveal that the amplitude and shape of the anomaly is insensitive to crustal thickness. Apart from the

Figure 10. (a) Schematic diagram showing basic parameters used in single-fault models. The crust is divided into three layers with densities of 2600,2750 , and $2900 \mathrm{~kg} / \mathrm{m}^{3}$, respectively. The water and mantle densities assumed are 1030 and $3300 \mathrm{~kg} / \mathrm{m}^{3}$, respectively. For each planar fault, dip angle $\alpha$ and downdip slip $s$ are specified. The darker shading corresponds to the portion of the mantle that is the source of the residual gravity anomaly. (b) Comparison of predicted gravity anomalies for a single fault with one, three, and five assumed crustal sublayers. Note that the three-layer model provides good approximation to the more complex five-layer model. (c) Kernels relating the predicted wavelengths of fault-induced topography and residual anomaly to the effective clastic plate thickness $T_{e}$. For all calculations, $\alpha=$ $45^{\circ}, s=1 \mathrm{~km}$, and the initial crustal thickness is $6 \mathrm{~km}$. 


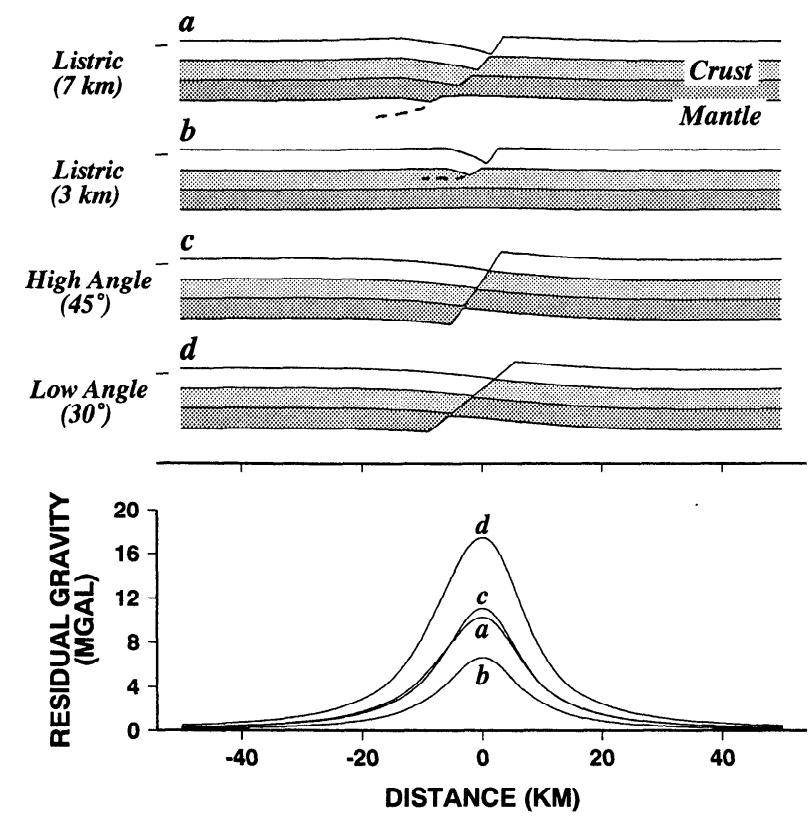

Figure 11. Two-dimensional models of crustal faulting assuming listric (models a and b) and planar geometries (models c and d). In all cases a 2-km vertical fault displacement at the seafloor is assumed. Note that the model of a low-angle fault propagating into the mantle produces the greatest gravity anomaly (model d), while the model of a listric fault restricted to the crust (model b) produces the least anomaly. Models a and $c$ have very similar geometries and similar resultant gravity anomalies.
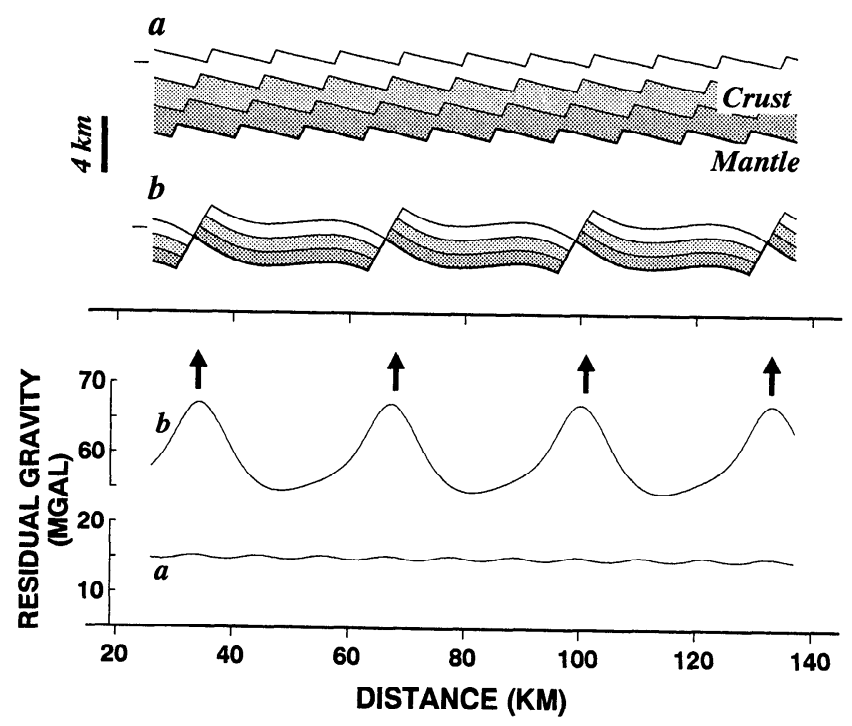

Figure 12. Two multiple-fault models both with $10 \%$ tectonic extension (defined as the ratio of horizontal displacement on each fault to fault spacing). Case a is characterized by $10-\mathrm{km}$ fault spacing, 1-km throw, and 6-km initial crustal thickness. Case b has $30 \mathrm{~km}$ of fault spacing, $3 \mathrm{~km}$ of throw, and $3 \mathrm{~km}$ of crustal thickness. Arrows show location of predicted gravity peaks. Note that gravity anomalies produced by small, closely spaced faults are too small to be recognizable in shipboard data with a noise level of 2-5 mGal. Larger and widely spaced faults, on the other hand, can produce significant gravity anomalies (case b). The average level of gravity anomalies is grater in case b because the initial crust thickness is smaller for case $b(3 \mathrm{~km})$ than for case a $(6 \mathrm{~km})$. differences in fault spacing and throw, the models in Figure 12 have initial crustal thicknesses of $6 \mathrm{~km}$ (case a) and $3 \mathrm{~km}$ (case b). A reduction in initial crustal thickness from 6 to $3 \mathrm{~km}$ increases the average level of the anomalies from $15 \mathrm{mGal}$ (case a) to $60 \mathrm{mGal}$ (case b) (Figure 12).

Consistent with the results of single-fault calculations (Figure 11), multiple-fault models also predict that lower dip angle and larger throw would result in larger gravity anomalies (Figures $13 \mathrm{a}$ and 13b). From simple geometrical arguments, the volume of the mantle material responsible for the calculated residual gravity anomaly high (darker shading in Figure 10) is $V=h c / \sin (\alpha)=s c / \tan (\alpha)$ where $h$ is the fault heave, $s$ the slip, $\alpha$ the angle, and $c$ the crustal thickness. In addition, multiple-fault models predict larger anomalies for more widely spaced faults. The results of Figure 13 thus indicate that, in the case of planar faults propagating into the mantle, only those faults with relatively large throws and relatively large spacings will produce residual gravity anomalies that are recognizable from the observed RMBA data.
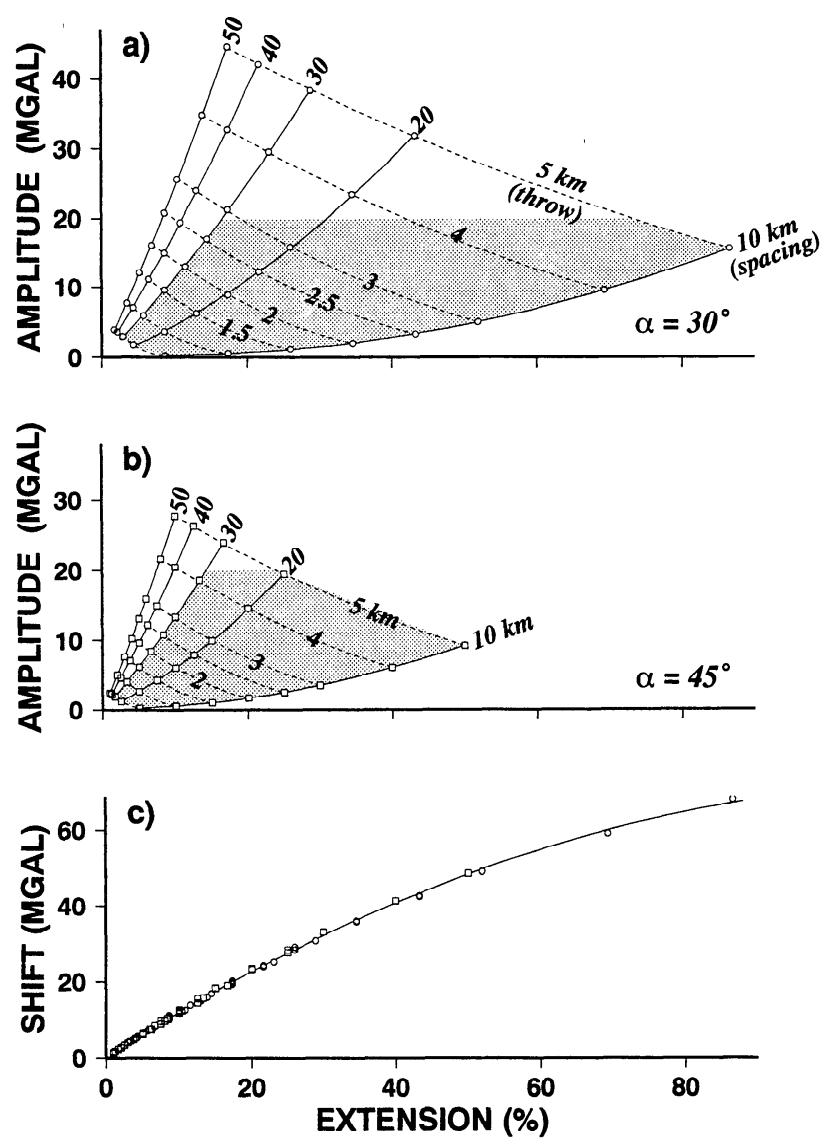

Figure 13. (a) (b) Kernels relating the peak-to-trough amplitude of gravity anomalies and the amount of crustal extension (percent) for different values of fault spacing and throw. (a) Planar faults with dip angles of $30^{\circ}$. (b) Planar faults with dip angles of $45^{\circ}$. The assumed initial crustal thickness is $6 \mathrm{~km}$ in all cases. Note that the amplitude of anomalies increases with increasing fault spacing and throw and decreasing dip angle. The shading oulines the area constrained by the measured spacing of gravity peaks (10-30 km, Figure 7) and the amplitude of the measured gravity peaks ( $<20 \mathrm{mGal}$, Figure 8$)$. (c) The shift in the average level of gravity anomalies increases with the amount of tectonic extension. 


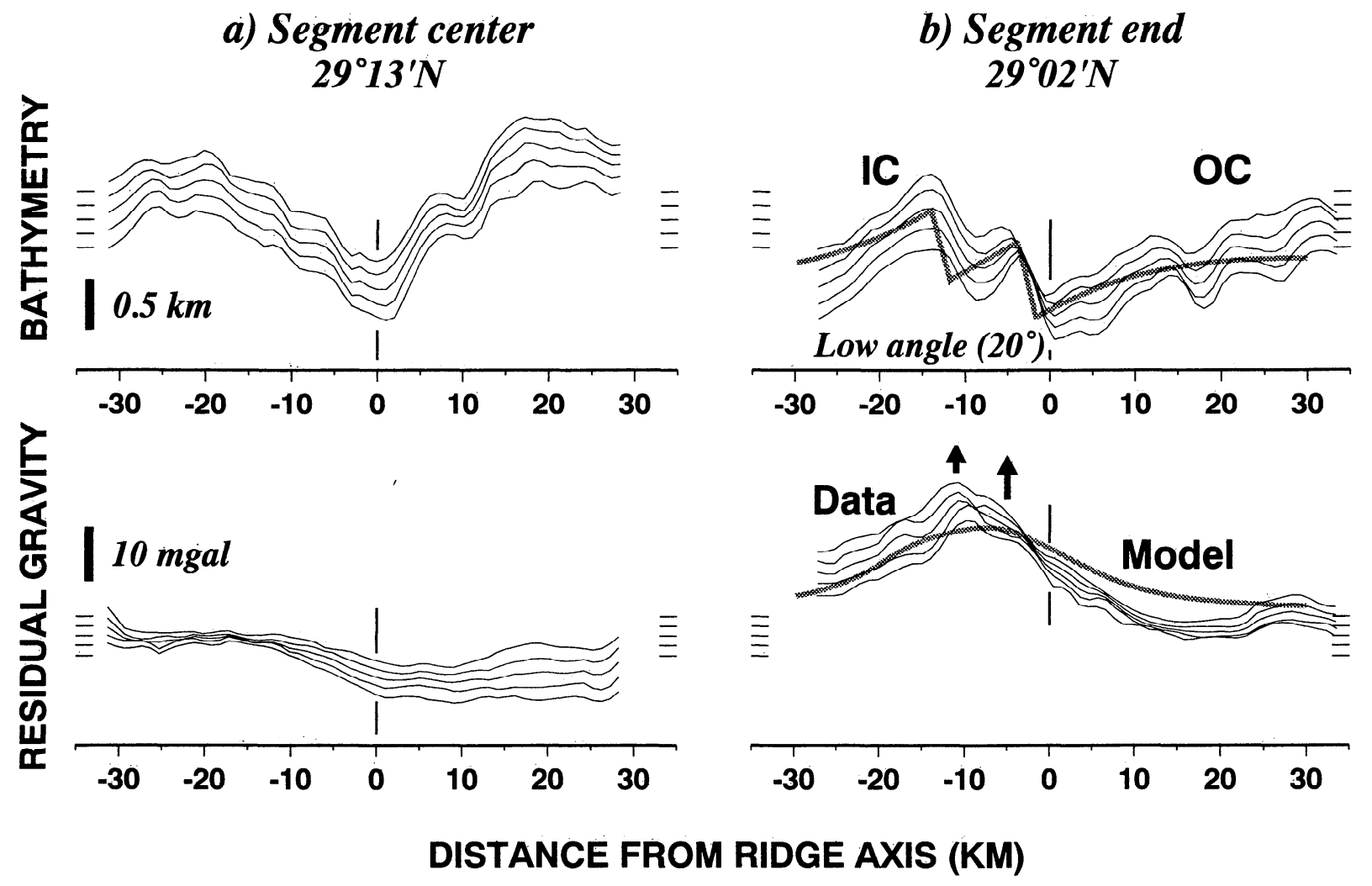

Figure 14. Stacked across-axis profiles in (top) bathymetry and (bottom) residual gravity at the (a) center and (b) the distal end of a MAR segment near $29^{\circ} \mathrm{N}$. Short horizontal lines on the left of each plot indicate the reference depths $(3 \mathrm{~km})$ and reference RMBA value $(15 \mathrm{mGal})$ for each individual profile. Note that the axial valley is more symmetric and the gravity anomaly is small at the segment center (Figure 14aa). Toward the distal end, however, the rift valley becomes more asymmetrical: its shape suggests that two large faults with large gravity anomalies are located at IC crust. Model calculations (gray lines) show that the gravity anomalies at IC crust can be accounted for by a model of two faults spaced $10 \mathrm{~km}$ apart, with throws of $0.8 \mathrm{~km}$ each, and a dip angle $\alpha$ of $20^{\circ}$.

\section{Comparison With the MAR Data}

Rift valley morphology and residual gravity anomalies vary significantly along slow-spreading ridges as illustrated in acrossaxis profiles across a MAR spreading segment near $29^{\circ} \mathrm{N}$ (Figure 14). Near the segment center the rift valley is symmetric, faults have small throws $(<0.75 \mathrm{~km})$, and the RMBA profiles are practically flat (Figure 14a). Near the segment end, in contrast, two major fault scarps with large gravity anomalies occur at IC crust (Figure 14b). This along-axis change in rift valley morphology is accompanied by deepening in axial seafloor (by $\sim 0.4 \mathrm{~km}$ from a to $\mathrm{b}$ ) and increase in the RMBA (by $\sim 15 \mathrm{mGal}$ from a to $b$ ).

The two faults at IC crust are $10 \mathrm{~km}$ apart with throws of $\sim 0.8$ $\mathrm{km}$ each. Assuming an initial crustal thickness of $4 \mathrm{~km}$ and a dip angle of $20^{\circ}$, we predict a gravity anomaly with an amplitude of $\sim 10 \mathrm{mGal}$ and a wavelength of $40 \mathrm{~km}$; this estimation resembles the observed RMBA (Figure 14b). Our calculations also reveal that the smaller $(<0.5 \mathrm{~km}$ throw) and more closely spaced $(<5$ km) faults near the segment center and at OC crust would produce RMBA anomalies with amplitudes $<3 \mathrm{mGal}$ (Figure 12).

To a first order, the low-angle fault model $\left(30^{\circ}\right.$ dip angle) also predicts the trend observed in the gravity peaks associated with individual fault scarps abutting the MAR axis (Figure 8). This low-angle fault model provides an approximate upper bound to the data near transforms (Figure 8a). Some anomalies in Figure $8 \mathrm{a}$ are smaller than predicted by this model, and they could be associated with steeper or more closely spaced faults. The remaining scattering in the data may reflect the complex lithologic structure of the lithosphere at slow spreading ridges [Cannat, 1993]. Since gravity solutions are non-unique and decay rapidly from source regions, future seismic mapping [e.g., Mutter and Karson, 1992] and near-bottom gravity surveys are required to further delineate more detailed structural differences between IC and OC crust.

\section{Discussion}

\section{Role of Transform Faults}

Transform offsets are characterized by the existence of a strike-slip fault that mechanically decouples the lithospheric plates created at adjacent spreading centers (Plate 1a). Data in Figure 8 show that fault scarps and the associated crustal thinning are systematically greater at IC crust than at OC crust. Such a strong tendency of large low-angle faults to develop at IC crust may be because less work is required to cause finite amplitude extension in IC crust which is decoupled across the transform fault (Figure 15). High elevations of IC crust may thus be the direct consequence of footwall uplifts associated with individual IC low-angle faults. Additional uplift could be produced by three-dimensional isostatic compensation to deep transform valley topography [Collette, 1986] and by visco-elastic stresses associated with ridge-transform shearing [Bercovici et al., 1992]. 


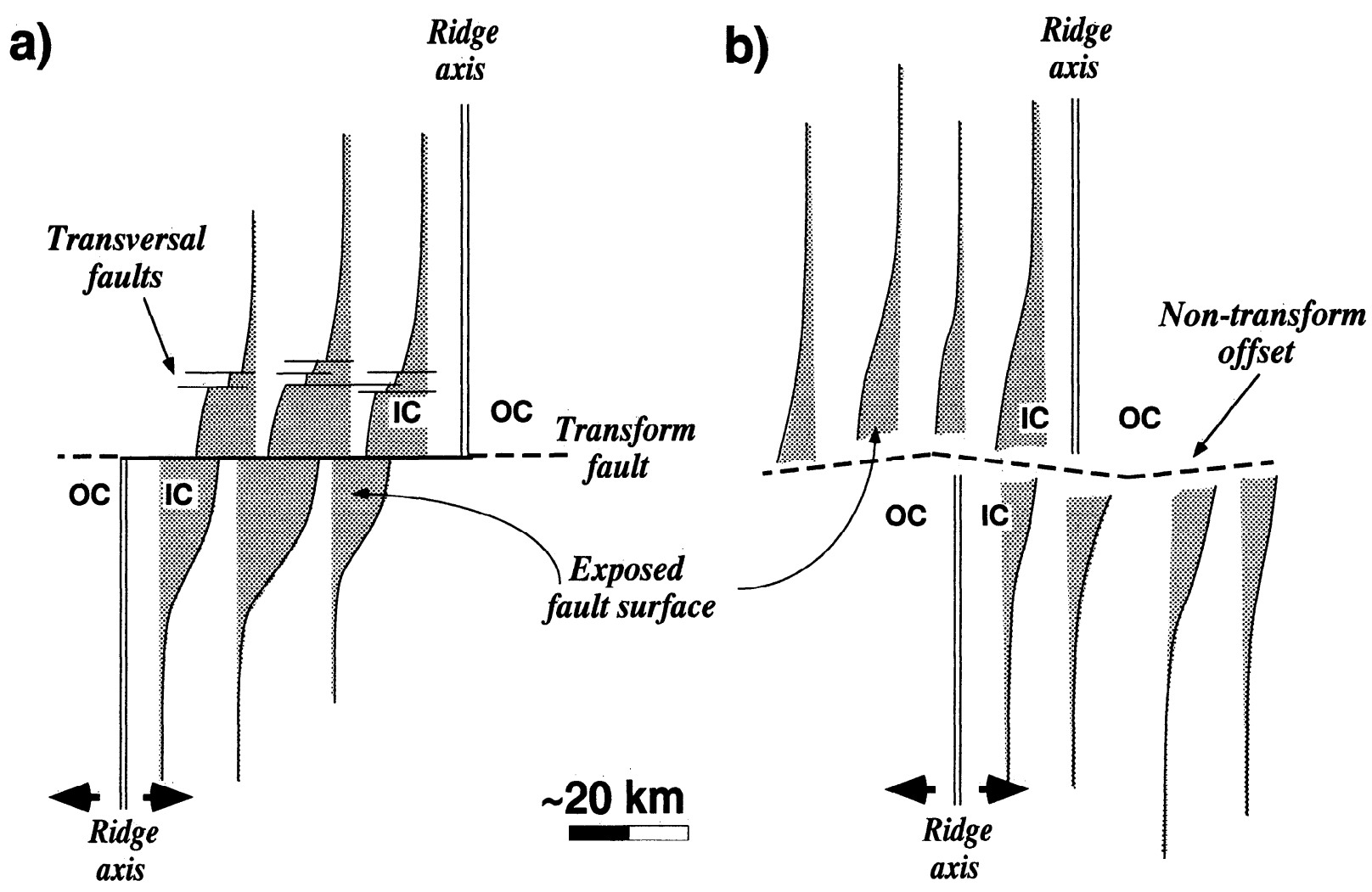

Figure 15. A model of along-axis changes in the structure of low-angle faults near (a) transforms and (b) nontransform offsets. Low-angle fault surfaces allow the exposure of lower crust and/or upper mantle rocks. We postulate that low-angle faults initiate preferentially at IC crust. These faults must die out gradually and may become higher angle toward segment centers. Secondary, axis-perpendicular transversal faults may dissect the low-angle faults and accommodate part of the decrease in fault throw toward segment centers. Toward ridge offsets, low-angle faults may be terminated either by a strike-slip fault along a transform (dashed line in Figure 15a) or an accommodation zone at a nontransform offset (dashed line in Figure 15b). Smaller, higher-angle normal faults at IC crust, OC crust and segment centers were not depicted.

Low-angle faults at IC crust must be finite in its along-axis length, as there is no evidence for exposed lower crust and upper mantle at segment centers or at OC crust [Tucholke and Lin, 1994]. Transform faults offer an optimal shear zone in which low-angle faults can terminate laterally toward the end of a segment. Low-angle faults must die out gradually toward the segment center, reducing fault throw and possibly steepening dip angle. This will result in the pinning of the exposed fault surface away from ridge offsets (shaded regions in Figure 15a). Minor transversal faults (thin lines in Figure 15a) could contribute to accommodate some along-axis variations in the strain distribution of low-angle faults [Dick et al., 1991] as earlier studies indicated [Karson, 1991; Cannat et al., 1993].

The spacing of the gravity spikes along IC crust near the MAR axis ranges from 10 to $50 \mathrm{~km}$, (Figure 8), similar to the spacing of fossil topographic highs on the transverse ridges bounding the Atlantis II Transform [Dick et al., 1991] and other MAR transverse ridges [Bonatti and Honnorez, 1976; Bonatti et al., 1983; Pockalny et al., 1988]. If, as proposed here, the gravity spikes are created by faults, the spacing implies that the formation of individual low-angle faults is a transient process that occurs episodically (every $\sim 2$ m.y.). At present, however, there is little data to constrain if the successive low-angle faults at IC crust of the MAR might be active simultaneously [cf. Shaw and Lin, 1993].

\section{Role of Nontransform Offsets}

Nontransform offsets differ from transform faults in a number of ways. First; instead of being associated with a well-defined strike-slip fault, a nontransform offset is often associated with a relatively wide deformation zone with complex morphology and tectonics [e.g., Searle and Laughton, 1977; Searle, 1979; Sempéré et al., 1993] (Plate 1b). Second, whereas off-axis traces indicate that transform faults are long-lived and relatively stable, nontransform offsets are commonly characterized by along-axis migrations and have a limited life span [e.g., Macdonald et al., 1991; Sempéré et al., 1993]. Third, the lack of a well-defined decoupling strike-slip fault across some nontransform offsets may require the differential slips between adjacent spreading segments be accommodated by along-axis ridge migration and overlapping normal faults [Grindlay et al., 1991]. Because of these differences between transforms and nontransform offsets, we expect low-angle faults to be smaller and the tendency of lowangle faults to occur at IC crust to be lesser near nontransform offsets (Figure 15b). This is consistent with the slightly smaller anomalies and the more diffuse transition between IC and OC domains in Figure 8. However, as in the case of transform offsets, detachment faults must also pin gradually toward segment centers. Occurrence of gravity spikes along the off-axis traces of some MAR nontransform offsets [Deplus et al., 1992; 
Tucholke et al., 1992; Lin et al., 1993; Rommeveaux et al., 1994] suggests that low-angle faults have similar life span near transform and nontransform offsets.

\section{Conclusions}

Our systematic analysis of high-resolution bathymetric and gravity data along the Mid-Atlantic Ridge and Southwest Indian Ridge reveals significant differences in crustal structure and tectonic faulting between inside and outside corner crust of these slow spreading ridges. A consistent pattern of positive residual gravity anomalies is found over elevated inside corner crust paralleling transform and nontransform offsets. Individual gravity spikes, which have amplitudes of up to $\sim 20 \mathrm{mGal}$ and across-axis spacings of 10-30 km (Figure 7), often coincide with individual fault scarps and may therefore reflect tectonic thinning of the crust by normal faulting. Theoretical calculations indicate that the amplitude and spacing of such gravity spikes can be adequately explained by the presence of successive, ridge-parallel low-angle faults. The gravity anomaly caused by individual faults is predicted to increase with increasing fault throw and spacing and decreasing dip angle. It is found that fault scarps and crustal thinning (as inferred from gravity anomalies) are consistently larger at inside corner crust than outside corner crust, indicating that tectonic extension near ridge offsets is asymmetric with low-angle faults occurring preferentially at inside corner crust.

Results of the analysis show significantly larger average inside corner versus outside corner asymmetries near transforms than nontransform offsets: the bathymetric asymmetry of individual transforms ranges from 0.4 to $1.0 \mathrm{~km}$ with a mean of $0.8 \mathrm{~km}$. In contrast, the corresponding asymmetry of nontransform offsets ranges from 0.0 to $0.8 \mathrm{~km}$ with a mean of $0.4 \mathrm{~km}$. Similarly, the gravity asymmetry of individual transforms ranges from 4.4 to $17.6 \mathrm{mGal}$ with a mean of $10 \mathrm{mGal}$, whereas asymmetry of nontransform offsets ranges from -0.3 to $14.2 \mathrm{mGal}$ with a mean of $5.7 \mathrm{mGal}$. Such contrasts in the degree of asymmetries may be related to the difference between transforms and nontransform offsets in the extent of lithospheric plate decoupling across the offsets.

The above results on spatial variations in seafloor morphology and gravity anomalies further support a three-dimensional tectonic faulting model at oceanic spreading centers. Low-angle faults may form preferentially at IC crust, where the mantle lithosphere is the strongest and the lithospheric plates are sufficiently decoupled across ridge-axis offsets. Low-angle faults must decreasc in throw toward midpoints of long ridge segments, where large low-angle faults may not be sustained by a weak lithosphere. Detail structure of such along-axis changes in fault geometry and their termination toward ridge-offsets are still poorly known at present and await further high-resolution geological, geophysical, and seismological studies.

Acknowledgments. We are grateful to R. Detrick for providing digital bathymetric and gravity data of parts of the MAR and to H. Dick and J. Snow for furnishing unpublished data of the SWIR. We benefited from discussion with C. Ruppel, B. Tucholke, P. Shaw, G. Jaroslow, H. Dick, and C. Wolfe, and editing by L. Pradiero. The manuscript was improved by thoughtful reviews of W. R. Buck, M. Cannat, and N. C. Mitchell. This work was supported by ONR grant N00014-91-J-1433 and NSF grant OCE-9012576. Javier Escartín also benefited from a Fellowship from "Caixa de Pensions La Caixa". Contribution 8751 of Woods Hole Oceanographic Institution.

\section{References}

Alexander, R. J., and G. D. Harper, The Josephine Ophiolite: An ancient analog for slow- to intermediate-spreading oceanic ridges, in Ophiolites and their modern oceanic analogues, edited by L. M. Parson, B. J. Murton, and P. Browning, Geol. Soc. Spec. Publ., London, 60, 3-38, 1992.

Alexander, R. J., G. D. Harper, and J. R. Bowman, Oceanic faulting and fault-controlled subseafloor hydrothermal alteration in the sheeted dike complex of the Josephine Ophiolite, J. Geophys. Res., 98, 97319759, 1993.

Barclay, A. H., D. R. Toomey, G. M. Purdy, and S. C. Solomon, FARA microearthquake experiments, III, Results from the Mid-Atlantic Ridge at $35^{\circ} \mathrm{N}$ (abstract), Eos Trans. AGU, 74 (43), Fall Meeting Suppl., 601, 1993.

Bercovici, D., H. J. B. Dick, and T. P. Wagner, Nonlinear viscoelasticity and the formation of transverse ridges, J. Geophys. Res., 97, 1419514206, 1992.

Blackman, D. K., and D. W. Forysth, Axial topographic relief associated with ridge-transform intersections, Earth Planet. Sci. Lett., 95, 115129, 1989.

Blackman, D. K., and D. W. Forysth, Isostatic compensation of tectonic features of the Mid-Atlantic Ridge: 25-27³0' S, J. Geophys. Res., 96, 11,741-11,758, 1991.

Bonatti, E., and J. Honnorez, Non-spreading crustal blocks at the MidAtlantic Ridge, Science, 174, 1329-1331, 1976.

Bonatti, E., R. Sartori, and A. Boresma, Vertical crustal movements at the Vema Fracture Zone in the Atlantic: Evidence from dredged limestone, Tectonophysics, 91, 213-223, 1983.

Buck, W. R., Effect of lithospheric thickness on the formation of highand low-angle normal faults, Geology, 21, 933-936, 1993.

Cannat, M., Emplacement of mantle rocks in the seafloor at mid-ocean ridges, J. Geophys. Res., 98, 4163-4172, 1993.

Cannat, M., et al., Crustal structure and axial segmentation Mid-Atlantic Ridge $21^{\circ}-24^{\circ} \mathrm{N}$ (abstract), Eos Trans. AGU, 74 (43), Fall Meeting Suppl., 664, 1993.

Cochran, J. R., An analysis of isostasy in the world's oceans, 2, Midocean ridges, J. Geophys. Res., 84, 4713-4730, 1979.

Collette, B. J., Fracture zones in the North Atlantic: Morphology and model, J. Geol. Soc. London, 143, 763-774, 1986.

Cormier, M.-H., K. C. Macdonald, and D. S. Wilson, A threedimensional gravity analysis of the East Pacific Rise from $18^{\circ}$ to $21^{\circ} 30^{\prime}$ S, J. Geophys. Res., in press, 1995.

Cowie, P. A., C. H. Scholz, M. Edwards, and A. Malinverno, Fault strain and seismic coupling on mid-ocean ridges, J. Geophys. Res., 98, 17,911-17,920, 1993.

Crane, K., The spacing of rift axis highs: Dependence upon diapiric processes in the underlying asthenosphere?, Earth Planet. Sci. Lett., 72, 405-414, 1985.

Deplus, C., M. Maia, D. Aslanian, and P. Gente, Segmentation of the mid-Atlantic ridge south of Kane fracture zone revealed by gravity anomalies (abstract), Eos Trans. AGU, 73 (43), Fall Meeting Suppl., 368, 1992.

Detrick, R. S., R. S. White, and G. M. Purdy, Crustal structure of North Atlantic fracture zones, Rev. Geophys., 31, 439-459, 1993.

Detrick, R. S., H. D. Needham, and V. Renard, Gravity anomalies and crustal thickness variations along the Mid-Atlantic Ridge between $33^{\circ} \mathrm{N}$ and $40^{\circ} \mathrm{N}, J$. Geophys. Res., in press, 1995.

Dick, H. J. B., Abyssal peridotites, very slow spreading ridges and ocean ridge magmatism, Geol. Soc. Spec. Publ. London 42, 71-105, 1989.

Dick, H. J. B., H. Schouten, P. S. Meyer, D. G. Gallo, H. Bergh, R. Tyce, P. Patriat, K. T. M. Johnson, J. Snow, and A. Fischer, Tectonic evolution of the Atlantis II Fracture Zone, Proc. Ocean Drill. Program Sci. Results, 118, 359-398, 1991.

Dula, W. F., Geometric models of listric normal faults and rollover folds, AAPG Bull., 75, 1609-1625, 1991.

Escartín, J., and J. Lin, Morfoestructura de la dorsal medio-Atlántica entre $24^{\circ} \mathrm{N}$ y $30^{\circ} \mathrm{N}$ (Morphotectonics of the Mid-Atlantic Ridge, $24^{\circ} \mathrm{N}$ - 30 N), Acta Geol. Hisp., 27, 33-49, 1992. 
Fujita, K., and N. Sleep, Membrane stress near mid-ocean ridgetransform intersections, Tectonophysics, 50, 207-221, 1978.

Gibbs, A. D., Balanced cross-section construction from seismic sections in areas of extensional tectonics, J. Sruct. Geol., 5, 153-160, 1983.

Grindlay, N. R., P. J. Fox, and K. C. Macdonald, Second-order axis discontinuities in the South Atlantic: Morphology, structure, and evolution, Mar. Geophys. Res., 13, 21-50, 1991.

Harper, G. D., Tectonics of slow-spreading mid-ocean ridges and consequences of a variable depth to the brittle/ductile transition, Tectonics, 4, 395-409, 1985.

Huang, P., and S. C. Solomon, Centroid depths of mid-ocean ridge earthquakes: Dependence on spreading rate, J. Geophys. Res., 93, 13,445-13,477, 1988.

Karson, J. A., Seafloor spreading on the Mid-Atlantic Ridge: Implications for the structure of ophiolites and oceanic lithosphere produced in slow-spreading environments, in Proceedings of the Symposium TROODOS 1987, edited by J. Malpas et al., pp. 547-555, Geological Survcy Department, Nicosia, Cyprus, 1990.

Karson, J. A., Accommodation zones and transfer faults: Integral components of mid-ocean ridge extensional systems, in Ophiolite Genesis and Evolution of the Oceanic lLthosphere, edited by T. J. Peters, A. Nicolas, and R. G. Coleman, pp. 21-37, Ministry of Petroleum and Minerals, Sultanate of Oman, Muscat, 1991.

Karson, J. A., and H. J. B. Dick, Tectonics of ridge-transform intersections at the Kane Fracture Zone, Mar. Geophys. Res., 6, 51-98, 1983.

Karson, J. A., and H. J. B. Dick, Deformed and metamorphosed crust on the Mid-Atlantic Ridge, Ofioliti, 9, 279-302, 1984.

King, G. C., R. S. Stein, and J. B. Rundle, The growth of geological structures by repeated earthquakes, 1 , Conceptual framework, $J$. Geophys. Res., 93, 13,307-13,318, 1988.

Kuo, B. Y., and D. W. Forsyth, Gravity anomalies of the ridge-transform system in the South Atlantic between 31 and $31^{\circ} \mathrm{S}$ : Upwelling centers and variations in crustal thickness, Mar. Geophys. Res., 10, 205-232, 1988.

Kuo, B. Y, J. Phipps Morgan, and D. W. Forsyth, Asymmetry in topography of the crestal mountains near a ridge-transform intersection (abstract), Eos Trans. $\Lambda G U, 65,274,1984$.

Lin, J., and E. A. Bergman, Rift grabens, seismicity and volcanic segmentation of the Mid-Atlantic Ridge: Kane to Atlantis Fracture Zones (abstract), Eos Trans. AGU, 71, 1572, 1990.

Lin, J., and E. M. Parmentier, A finite amplitude necking model of rifting in brittle lithosphere, J. Geophys. Res., 95, 4909-4923, 1990.

Lin, J., and J. Phipps Morgan, The spreading rate dependence of threedimensional mid-ocean ridge gravity structure, Geophys. Res. Lett., 19, 13-15, 1992.

Lin, J., G. M. Purdy, H. Schouten, J. C. Sempéré, and C. Zervas, Evidence from gravity data for focused magmatic accretion along the Mid-Atlantic Ridge, Nature, 344, 627-632, 1990.

Lin, J., B. E. Tucholke, and M. C. Kleinrock, Evidence from gravity and morphology for long-term variability in magmatic vs. tectonic extension at the Mid-Atlantic Ridge (abstract), Eos Trans. AGU, 74 (16), Spring Meeting Suppl., 303, 1993.

Louden, K. E., and D. W. Forsyth, Crustal structure and isostatic compensation near the Kane fracture zone from topography and gravity measurements, I, Spectral analysis approach, Geophys. J. $R$. Astron. Soc., 68, 725-750, 1982.

Macdonald, K. C., and B. P. Luyendyk, Deep-tow studies of the structure of the Mid-Atlantic Ridge crest near lat $37^{\circ} \mathrm{N}$, Geol. Soc. Am Bull., 88 , 621-636, 1977.

Macdonald, K. C., D. S. Scheirer, and S. M. Carbotte, Mid-ocean ridges: Discontinuities, segments and giant cracks, Science, 253, 986-994, 1991.

Madsen, J. A., R. S. Detrick, J. C. Mutter, P. Buhl, and Orcutt, A twoand three-dimensional analysis of gravity anomalies associated with the East Pacific Rise at $9^{\circ} \mathrm{N}$ and $13^{\circ} \mathrm{N}$, J. Geophys. Res., $95,4967-$ 4987, 1990.

McKenzie, D., and C. Bowin, The relationship between bathymetry and gravity in the Atlantic Ocean, J. Geophys. Res., 81, 1903-1915, 1976.
Mével, C., M. Cannat, P. Gente, E. Marion, J. M. Auzende, and J. A. Karson, Emplacement of deep crustal and mantle rocks on the west median valley wall of the MARK area (MAR, $\left.23^{\circ} \mathrm{N}\right)$, Tectonophysics, 190, 31-53, 1991.

Mitchell, N. C., Distributed extension at the Indian Ocean triple junction, J. Geophys. Res., 96, 8019-8043, 1991.

Morris, E., and R. S. Dctrick, Three-dimensional analysis of gravity anomalies in the MARK area, Mid-Atlantic Ridge $23^{\circ} \mathrm{N}, J$. Geophys. Res., 96, 4355-4366, 1991.

Mutter, J. C., and J. A. Karson, Structural processes at slow-spreading ridges, Science, 257, 627-634, 1992.

Neumann, G. A., and D. W. Forsyth, The paradox of the axial profile: Isostatic compensation along the axis of the Mid-Atlantic Ridge?, $J$. Geophys. Res., 98, 17,891-17,910, 1993.

Parker, R. L., The rapid calculation of potential anomalies, Geophys. J. R. Astron. Soc., 31, 447-455, 1973.

Parmentier, E. M., and J. Phipps Morgan, Spreading rate dependence of three dimensional structure in oceanic spreading centres, Nature, 348, 325-328, 1990.

Phipps Morgan, J., and D. W. Forsyth, Three-dimensional flow and tempcraturc perturbations due to a transform offset: Effects on oceanic crustal and upper mantle structure, I. Geophys. Res., 93, 2955-2966, 1988.

Pockalny, R. A., R. S. Detrick, and P. J. Fox, Morphology and tectonics of the Kane transform from Sea Beam bathymetry data, J. Geophys. Res., 93, 3179-3193, 1988.

Pollard, D. D., and A. Aydin, Propagation and linkage of oceanic ridge segments, J. Geophys. Res., 89, 10017-10028, 1984.

Purdy, G. M., J. C. Sempéré, H. Schouten, D. L. Dubois, and R. Goldsmith, Bathymetry of the Mid-Atlantic Ridge, $24^{\circ}-31^{\circ} \mathrm{N}$ : A map series, Mar. Geophys. Res., 12, 247-252, 1990.

Rabinowicz, M., A. Nicolas, and J. L. Vigneresse, A rolling mill effect in asthenosphere beneath oceanic spreading centers, Earth Planet. Sci. Lett., 67, 97-108, 1984.

Rommeveaux, C., C. Deplus, P. Patriat, and J.-C. Sempéré, Threedimensional gravity study of the Mid-Atlantic Ridge: Evolution of the segmentation between $28^{\circ}$ and $29^{\circ} \mathrm{N}$ during the last 10 m.y., $J$. Geophys. Res., 99, 3015-3029, 1994.

Ruppel, C., and P. Shaw, An elastic plate thickness map of the MidAtlantic Ridge between the Kane and Atlantis Fracture Zones, (abstract), Eos Trans. AGU, 73 (43), Fall Meeting Suppl., 571, 1992.

Schouten, H., K. D. Klitgord, and J. A. Whitehead, Segmentation of midocean ridges, Nature, 317, 225-229, 1985.

Searle, R. C., Side-scan sonar studies of North Atlantic fracture zones, $J$. Geol. Soc. London, 136, 283-292, 1979.

Searle, R. C., and A. S. Laughton, Sonar studies of the Mid-Atlantic Ridge and Kurchatov Fracture Zone, J. Geophys. Res., 82, 5313-5328, 1977.

Sempéré, J. C., J. Lin, H. S. Brown, H. Schouten, and G. M. Purdy, Segmentation and morphotectonic variations along a slow-spreading center: The Mid-Atlantic Ridge $\left(24^{\circ} \mathrm{N}-30^{\circ} 40^{\prime} \mathrm{N}\right)$, Mar. Geophys. Res., 15, 153-200, 1993.

Severinghaus, J. P., and K. C. Macdonald, High inside corners at ridgetransform intersections, Mar. Geophys. Res., 9, 353-367, 1988.

Shaw, P. R., Ridge segmentation, faulting and crustal thickness in the Atlantic Ocean, Nature, 358, 490-493, 1992.

Shaw, P. R., and J. Lin, Causes and consequences of variations in faulting style at the Mid-Atlantic Ridge, J. Geophys. Res., 98, 21839-21851, 1993.

Shaw, W. J., and J. Lin, Threc-dimensional modeling of thermomechanical structure of oceanic spreading centers: Effects of alongaxis thickness variations associated with segmentation and hot spots (abstract), Eos Trans. AGU, 75 (16), Spring Meeting Suppl., 331, 1994.

Sinha, M. C., and K. E. Louden, The Oceanographer fracture zone, I, Crustal structure from seismic refraction studies, Geophys. J. $R$. Astron. Soc., 75, 713-736, 1983.

Solomon, S. C., P. Y. Huang, and L. Mcinke, The seismic moment budget of slowly spreading ridges, Nature, 334, 58-60, 1988. 
Sparks, D. W., E. M. Parmentier, and J. Phipps Morgan, Threedimensional convection beneath a segmented spreading segment: Implications for along-axis variations in crustal thickness and gravity, spreading centers, J. Geophys. Res., 98, 21977-21995, 1993.

Stein, R. S., G. C. King, and J. B. Rundle, The growth of geological structures by repeated earthquakes, 2, Field examples of continental dip-slip faults, J. Geophys. Res., 93, 13319-13331, 1988.

Tolstoy, M., A. J. Harding, and J. A. Orcutt, Crustal thickness on the Mid-Atlantic Ridge: Bull's eye gravity anomalies and focused accretion, Science, 262, 726-729, 1993.

Tucholke, B. E., Massive submarine rockslide in the rift-valley wall of the Mid-Atlantic Ridge, Geology, 20, 129-132, 1992.

Tucholke, B. E., and J. Lin, A geological model for the structure of ridge segments in slow spreading ocean crust, J. Geophys. Res., 99, 11,93711,958, 1994.

Tucholke, B. E., J. Lin, and M. C. Kleinrock, Crustal structure of spreading segments on the western flank of the Mid-Atlantic Ridge at $25^{\circ} 25^{\prime} \mathrm{N}$ to $27^{\circ} 10^{\prime} \mathrm{N}$ (abstract), Eos Trans. AGU, 73 (43), Fall Meeting Suppl., 537, 1992.
Wang, X., and J. R. Cochran, Gravity anomalies, isostasy, and mantle flow at the East Pacific Rise, J. Geophys. Res., 98, 19,505-19,531, 1993.

Weissel, J. K., and G. D. Karner, Flexural uplift of rift flanks due to mechanical unloading of the lithosphere during extension, J. Geophys. Res. , 94, 13,919-13,950, 1989.

Whitehead, J. A., H. J. B. Dick, and H. Schouten, A mechanism for magmatic accretion under spreading centres, Nature, 312, 146-148, 1984.

J. Escartín and J. Lin, Department of Geology and Geophysics, Woods Hole Oceanographic Institution, Woods Hole, MA 02543 (e-mail: javier@galileo.whoi.edu; jlin@whoi.edu)

(Received June 21, 1994; revised November 29, 1994; accepted December 6, 1994.) 